\title{
TerraSAR-X and Wetlands: A Review
}

\author{
Christian Wohlfart ${ }^{1, *(\mathbb{D})}$, Karina Winkler ${ }^{1,2,3}$, Anna Wendleder ${ }^{1}$ and Achim Roth ${ }^{1}$ \\ 1 German Remote Sensing Data Center (DFD), German Aerospace Center (DLR), Muenchener Strasse 20, \\ 82234 Wessling, Germany; karina.winkler@dlr.de (K.W.); anna.wendleder@dlr.de (A.W.); \\ achim.roth@dlr.de (A.R.) \\ 2 Company for Remote Sensing and Environmental Research (SLU), Kohlsteiner Strasse 5, \\ 81243 Munich, Germany \\ 3 Institute of Meteorology and Climate Research (IMK-IFU), Karlsruhe Institute of Technology (KIT), \\ Kreuzeckbahnstr. 19, 82467 Garmisch-Partenkirchen, Germany \\ * Correspondence: christian.wohlfart@dlr.de; Tel.: +49-8153-28-3418
}

Received: 17 April 2018; Accepted: 8 June 2018; Published: 10 June 2018

\begin{abstract}
Since its launch in 2007, TerraSAR-X observations have been widely used in a broad range of scientific applications. Particularly in wetland research, TerraSAR-X's shortwave X-band synthetic aperture radar (SAR) possesses unique capabilities, such as high spatial and temporal resolution, for delineating and characterizing the inherent spatially and temporally complex and heterogeneous structure of wetland ecosystems and their dynamics. As transitional areas, wetlands comprise characteristics of both terrestrial and aquatic features, forming a large diversity of wetland types. This study reviews all published articles incorporating TerraSAR-X information into wetland research to provide a comprehensive study of how this sensor has been used with regard to polarization, and the function of the data, time-series analyses, or the assessment of specific wetland ecosystem types. What is evident throughout this literature review is the synergistic fusion of multi-frequency and multi-polarization SAR sensors, sometimes optical sensors, in almost all investigated studies to attain improved wetland classification results. Due to the short revisiting time of the TerraSAR-X sensor, it is possible to compute dense SAR time-series, allowing for a more precise observation of the seasonality in dynamic wetland areas as demonstrated in many of the reviewed studies.
\end{abstract}

Keywords: synthetic aperture radar; X-band; marine; estuarine; lacustrine; riverine; palustrine; time-series; SAR applications; vegetation; remote sensing data

\section{Introduction}

Wetlands are among the most biologically diverse and productive ecosystems in the world. Home to a large variety of floral and faunal communities, wetlands provide essential ecosystem services and goods of great ecological and economic value to millions of people [1-4]. Their services include water quality preservation, erosion control and sediment retention, groundwater recharge, reducing risks of storm surges and flooding, and climate change mitigation [5-7]. Covering approximately $6 \%$ of the Earth's surface, wetland soils hold a disproportionate amount of carbon, accounting for around $12 \%$ of global carbon stocks [6,8], and therefore play a critical role in global carbon dynamics [9].

Despite their recognition as one of the most valuable natural resources, major wetland areas have irreversibly diminished or deteriorated and subsequently lost their functional properties with significant repercussions on ecological, economic, social, and cultural benefits [10]. During the 20th and 21 st centuries, around $64 \%$ of the natural wetlands have been vanished and continue to disappear at an annual loss rate of $1 \%$, although this pace is slowing [11]. Anthropogenic factors are the main reason for the disappearing wetland resources, including the conversion of wetlands to urban or agricultural land, damming, or pollution, being more pronounced in inland ecosystems in light of the 
aforementioned benefits. To counteract the continued decline, there is an increasing need to detect and monitor the ecosystem remnants. Precise spatio-temporal information about wetland cover and their dynamics are central components for establishing effective conservation strategies, and help to understand the underlying drivers of change [12,13].

The spatial diversity and complexity of wetland ecosystems around the world make wetland identification and mapping a challenging task. Over the past several decades, the domain of remote sensing techniques has greatly advanced in terms of sensor variety and derived products to exploit new fields of application to understand Earth surface cover and dynamics [14]. A fleet of various remote sensing sensors, including both optical and radar, has been used to identify, delineate, and classify the extent and quality of wetland ecosystems on different spatial scales, given their ability to monitor large areas in a comparatively short period of time [15-20]. So far, scientific studies have put more emphasis on optical sensors (Figure 1), although radar systems offer great potential in delineating unique wetland characteristics, including species composition, water surface detection, vegetation health, or structural properties $[17,21,22]$.

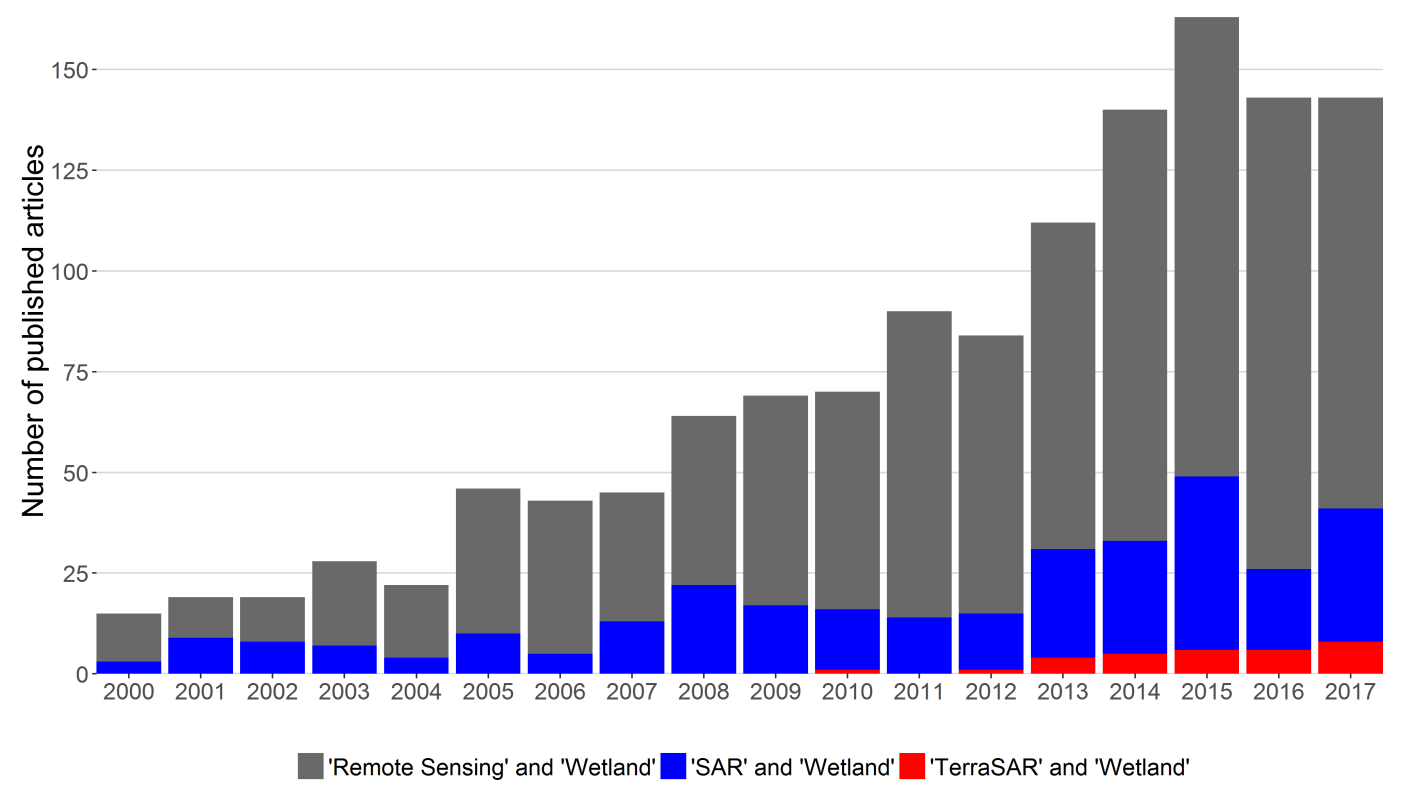

Figure 1. Number of wetland publications using remote sensing (gray), synthetic aperture radar (SAR, blue), and TerraSAR-X (red) data from 2000 to 2017.

Synthetic aperture radar (SAR) technology provides complementary and supplementary information to multi- and hyperspectral or thermal sensors, since, in the microwave spectrum, radar frequently monitors at the increased spatial resolution necessary for mapping wetlands. In contrast to sensors operating in the optical and thermal range, pulsed SAR signals can penetrate the clouds and haze that are very common in cloud-prone wetland regions, as well as image surfaces during low-light conditions in near-real-time $[17,23]$. Furthermore, SAR has the ability, to varying degrees, to penetrate vegetation canopies for the delineation of understory information, and is sensitive to dielectric properties such as soil moisture and inundation level. Evidently, scientific reviews about the radar remote sensing of wetland ecosystems began appearing in the literature in the 1990s [17,22,24-28]. These published studies published describe the optimal relationship between SAR specifications (wavelength, polarization, incidence angle, spatial resolution) and specific ground features of wetlands (e.g., structure, roughness, dielectric constant). Since the launch of the first spaceborne SAR missions including NASA's Spaceborne Imaging Radar (SIR) and ESA's European Remote Sensing (ERS) satellites [29], many studies have used this new source of data for wetland applications. With the 
recent development of very-high-resolution SAR sensors such as RADARSAT-2 and TerraSAR-X, new possibilities in wetland research have emerged. TerraSAR-X provides unprecedented opportunities for wetland assessment, since its $X$-band signal $(3.1 \mathrm{~cm}$ wavelength) has proven suitable for observing tidal flats [30] or herbaceous wetlands with higher levels of detail and resolutions than other SAR sensors [31].

To date, there is no comprehensive literature review about the potential and range of applications TerraSAR-X provides with regard to wetland analyses. This paper aims to close this gap by providing an update to existing wetland-radar review studies explicitly describing wetland-related research with a specific focus on high-resolution and high-frequency TerraSAR- $X$ data. The next section briefly introduces the wetland types and characterization we used in this study followed by a section about the methodology in the review process. Then, SAR principles and backscatter mechanisms in mapping wetland characteristics are pictured. Section 5 provides the reader with a detailed and comprehensive overview of how TerraSAR-X data have been used in wetland-related research, including sensor specifications, function of TerraSAR-X data and wetland categories. The paper finishes with some concluding remarks.

\section{Wetland Concept, Types, and Characteristics}

Wetlands are often characterized as transitional ecotones forming at the interface of terrestrial and aquatic ecosystems and, hence, holding features of both [32]. While variations in appearance and species composition may be high, temporary or permanent inundation by water is a common feature that shapes plant adaption, soil processes, as well as animal life [33,34]. The Ramsar Convention established a broad concept of wetlands in 1971, which represents the most commonly used, internationally accepted wetland definition. According to this, wetlands are described as

"areas of marsh, fen, peatland or water, whether natural or artificial, permanent or temporary, with water that is static or flowing, fresh, brackish or salt, including areas of marine water the depth of which at low tide does not exceed six metres" [35]. 
Table 1. Overview of characteristics and functions of major natural wetland types according to the Ramsar international wetland classification [36,37] and TerraSAR-X-related studies, respectively (based on: $[28,33,34]$ ).

\begin{tabular}{|c|c|c|c|}
\hline Wetland Type & Characteristics & Functions & Selected Studies Using TerraSAR-X \\
\hline \multicolumn{4}{|c|}{ Marine and Coastal Wetlands (Mostly Marine and Estuarine) } \\
\hline G: Intertidal (salt) flats & $\begin{array}{l}\text { Non-vegetated shore with tidal flooding (salt } \\
\text { restricting plant growth) }\end{array}$ & $\begin{array}{l}\text { Shoreline stabilization; Nutrient and } \\
\text { sediment retention; Vital habitats for } \\
\text { clams, crabs, and juvenile fish }\end{array}$ & $\begin{array}{l}\text { Gade et al. (2014 [38], } 2018 \text { [39]); Gade \& } \\
\text { Melchionna (2016) [40]; Kim et al. } \\
\text { (2011) [41]; Jung et al. (2015) [42] }\end{array}$ \\
\hline $\begin{array}{l}\text { H: Intertidal (salt) marshes, } \\
\text { freshwater marshes }\end{array}$ & $\begin{array}{l}\text { Herb-dominated shores with tidal/long-term } \\
\text { flooding during the year (often with halophytic } \\
\text { plants) and hydric soils }\end{array}$ & $\begin{array}{l}\text { Carbon sequestration; Nutrient and } \\
\text { sediment retention; Water-quality } \\
\text { renovation; Wildlife habitat }\end{array}$ & $\begin{array}{l}\text { Lee et al. (2011) [43]; Da Lio et al. } \\
\text { (2018) [44] }\end{array}$ \\
\hline $\begin{array}{l}\text { I: Intertidal forested wetlands } \\
\text { (mangrove and tidal } \\
\text { freshwater swamps) }\end{array}$ & $\begin{array}{l}\text { Tree-dominated shores with tidal/long-term } \\
\text { flooding during the year and hydric soils }\end{array}$ & $\begin{array}{l}\text { Carbon sequestration; Valuable } \\
\text { habitat for fish and crustacean } \\
\text { species; Coastal protection; } \\
\text { Water-quality renovation; } \\
\text { Production of timber }\end{array}$ & $\begin{array}{l}\text { Hong et al. (2010 [45], 2015 [46]); } \\
\text { Lagomasino et al. (2016) [47] }\end{array}$ \\
\hline \multicolumn{4}{|c|}{ Inland Wetlands (Lacustrine, Riverine, Palustrine) } \\
\hline Peatlands & Peat-forming soils & $\begin{array}{l}\text { Carbon sequestration in the form of } \\
\text { peat; Provision of substrate; Bird } \\
\text { breeding and wildlife habitat }\end{array}$ & \\
\hline $\begin{array}{l}\text { Xp: Forested peatlands } \\
\text { (peatswamp forest) }\end{array}$ & Tree-dominated & & $\begin{array}{l}\text { Wijaya et al. (2010) [51]; Englhart et al. } \\
\text { (2011) [52]; }\end{array}$ \\
\hline Marshes and swamps & Inorganic soils & $\begin{array}{l}\text { Carbon sequestration; Water-quality } \\
\text { renovation; Bird breeding and } \\
\text { wildlife habitat; Production } \\
\text { of timber }\end{array}$ & $\begin{array}{l}\text { Irwin et al. (2017) [53]; Betbeder et al. } \\
\text { (2014) [31]; Parker et al. (2017) [54] }\end{array}$ \\
\hline S/T: Marshes/pools & $\begin{array}{l}\text { saline/brackish/alkaline or freshwater, } \\
\text { herb-dominated }\end{array}$ & & \\
\hline \multicolumn{4}{|l|}{ W: Shrub-dominated wetlands } \\
\hline Xf: Tree-dominated wetlands & & & \\
\hline
\end{tabular}


Due to the diversity of wetlands that exist around the globe, they can be categorized according to numerous classification schemes relying on biological, physical, chemical, hydrogeomorphological variables or functions [34]. Although many wetland classification systems have been developed by scientists at regional and national levels, the Ramsar Convention on Wetlands established the first globally consistent classification framework [37] in order to characterize wetlands of international importance $[34,55]$. Generally, five major wetland types are distinguished according to their landscape features and formation [56].

- $\quad$ marine (coastal wetlands such as lagoons, shores, and coral reefs)

- $\quad$ estuarine (deltas, tidal marshes, mudflats, and mangrove swamps)

- lacustrine (wetlands associated with lakes)

- $\quad$ riverine (wetlands along rivers and streams)

- $\quad$ palustrine ("marshy" wetlands like marshes, swamps, and bogs)

Additionally, lhuman-made wetlands such as aquaculture ponds, salt pans, dams, and reservoirs are recognized. The Convention has adopted these types in its Ramsar Classification of Wetland Types, which comprises 42 types grouped into the categories Marine and Coastal Wetlands, Inland Wetlands, and Human-Made Wetlands [56]. This has gained widespread acceptance, and thus is used as a foundation for categorizing wetland types in this study. Table 1 displays a summarized representation of major wetland types, their description, functions, and TerraSAR-X related studies, respectively. Since the focus was laid on natural wetlands, studies focusing explicitly on human-made wetlands such as aquacultures and irrigated areas were excluded from the analysis.

\section{Data and Methodology}

Both the comprehensive Scientific Citation Index Extented (SCIE) database from Web of Science and Elsevier's Scopus database were used for the literature review. To get an overview of remote sensing-based studies related to wetlands as well as those using SAR and explicitly TerraSAR-X data, we applied a search based on the keyword string combinations of "wetland" with "remote sensing", "SAR", and "TerraSAR-X", respectively.

The scientific literature related to wetlands using remote sensing applications is rapidly growing. Studies using radar remote sensing still represent a minor part of all remote sensing-based publications on wetlands. However, numbers have continuously increased since 2000. Especially in the last decade, the usage of newly available sensors such as TerraSAR-X has steadily grown and contributed to this development (see Figure 1).

In order to obtain a consistent database of published articles on the remote sensing of wetlands using TerraSAR-X data, we used a combination of "TerraSAR-X" with of one of the following keywords: "wetland", "mangrove", "peat", "bog", "fen", "marsh", and "swamp". After revising the entries and excluding papers without the usage of TerraSAR-X images or without a focus on (semi-)natural wetlands, a total of 32 articles were obtained. Table A1 in the Appendix summarizes all selected studies for this review.

Figure 2 shows the spatial distribution of study sites from the selected publications and major wetland areas. 


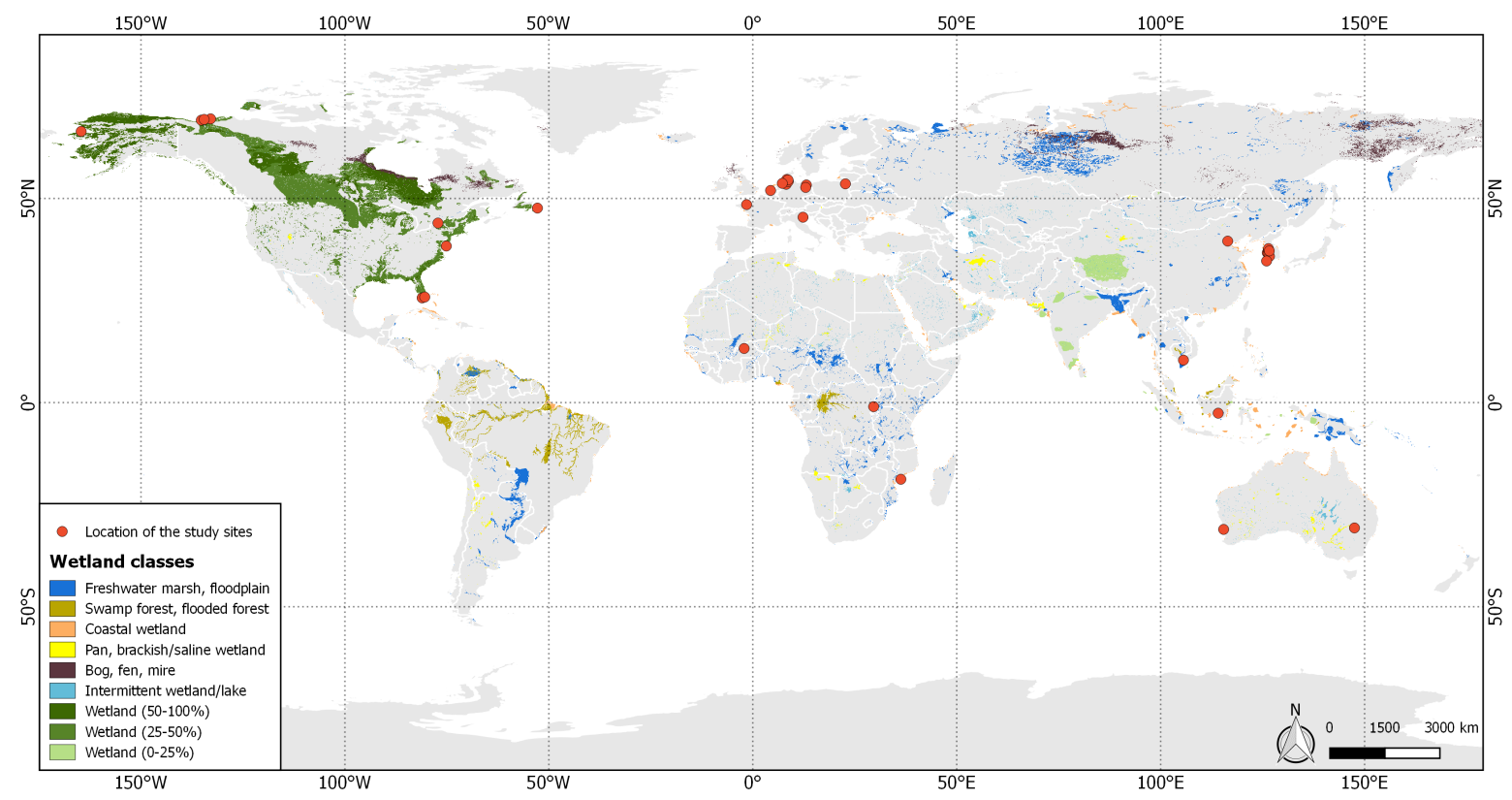

Figure 2. Generalized global distribution of wetland types based on Lehner et al. [57] and location of the study sites of published TerraSAR-X-related articles.

\section{SAR Principles for Mapping Wetland Characteristics}

SAR is a common imaging radar technology, and has been widely used in wetland-related studies. As an active sensor, SAR measures the receipt (backscatter) of an actively transmitted pulse, and therefore offers unique characteristics that make it ideal for mapping and monitoring wetland features. The electromagnetic spectrum is sampled at much longer wavelengths compared to optical sensors, which usually operate in the visible and infrared spectrum. The ability of radar to penetrate through clouds makes this sensor particularly valuable for the detection of wetlands, which are usually distributed across areas with frequent cloud coverage. Furthermore, radar backscatter is sensitive to dielectric properties including inundation level, soil moisture, or salinity, which are common features of wetland ecosystems [17]. SAR data are often categorized by their wavelength (e.g., X-band with $3.1 \mathrm{~cm}$, C-band with $5.6 \mathrm{~cm}$, and L-band with $23.6 \mathrm{~cm}$ ) or polarization (e.g., $\mathrm{HH}=$ horizontally transmitted and received and VV = vertically transmitted and received). The pulsed radar beam is transmitted at different angles relative to the surface (look angles). Thus, a radar image provides structural and textural information about the land surface [58]. The relationship of these sensor parameters to the scattering mechanisms of wetland vegetation types have been shown in many scientific reviews $[17,22,24-26,28]$. Figure 3 provides a simplified illustration of the basic backscatter mechanisms related to different wetland characteristics for the most commonly used SAR bands. Four general backscattering types can be distinguished:

- $\quad$ surface scattering (rough surface reflects transmitted radiation in all directions)

- $\quad$ specular scattering (smooth surface reflects radiation away from the sensor)

- volume scattering (radiation is both reflected and refracted/transmitted in an object or volume)

- double-bounce scattering (radiation is reflected on two perpendicular planes)

When there is dry soil cover accompanied by herbaceous vegetation or small shrubs which create a rougher surface, surface reflection is the dominant scattering mechanism at both short and long wavelengths, whereas longer wavelengths show a greater penetration into the dry soil. Denser vegetation can also result in volume scattering. On smoother surfaces, the reflection becomes specular for shorter and longer wavelengths. Smooth surfaces are calm water where the signal is reflected away from the sensor due to the dielectric constant or bare soils where the surface 
roughness is smaller than the wavelength of the sensor. For flooded vegetation such as reed, short wavelength scatter is dominated by volume scattering in dense vegetation structure. For example, X-band backscatter mainly interacts with leaves, twigs, and small branches, and thus is sensitive to herbaceous vegetation [52]. In addition, double-bounce can occur between two smooth surfaces, such as water and vertical emergent vegetation. In contrast, longer wavelengths penetrate through herbaceous vegetation, resulting in specular scattering, assuming little water roughness. Forests cause volume scattering within dense canopies at shorter wavelengths, because the electromagnetic signal is not able to penetrate the crown cover. Longer wavelengths appear to scatter from branches and tree structures in combination with double-bounce backscatter, whereas inundated forests amplify the double-bounce scatter. Another important parameter which influences the scattering mechanism is the incidence angle, which describes the angle between the radar beam and the vertical (normal) direction to the intercepting surface. The selection of an appropriate incidence angle depends on the research goal [59]. Smaller incidence angles (less than 28 degrees) are able to better penetrate vegetation and can potentially map sub-canopy water. Furthermore, smaller incidence angles reduce the effect of shadow, particularly in regions with distinct topography $[60,61]$.
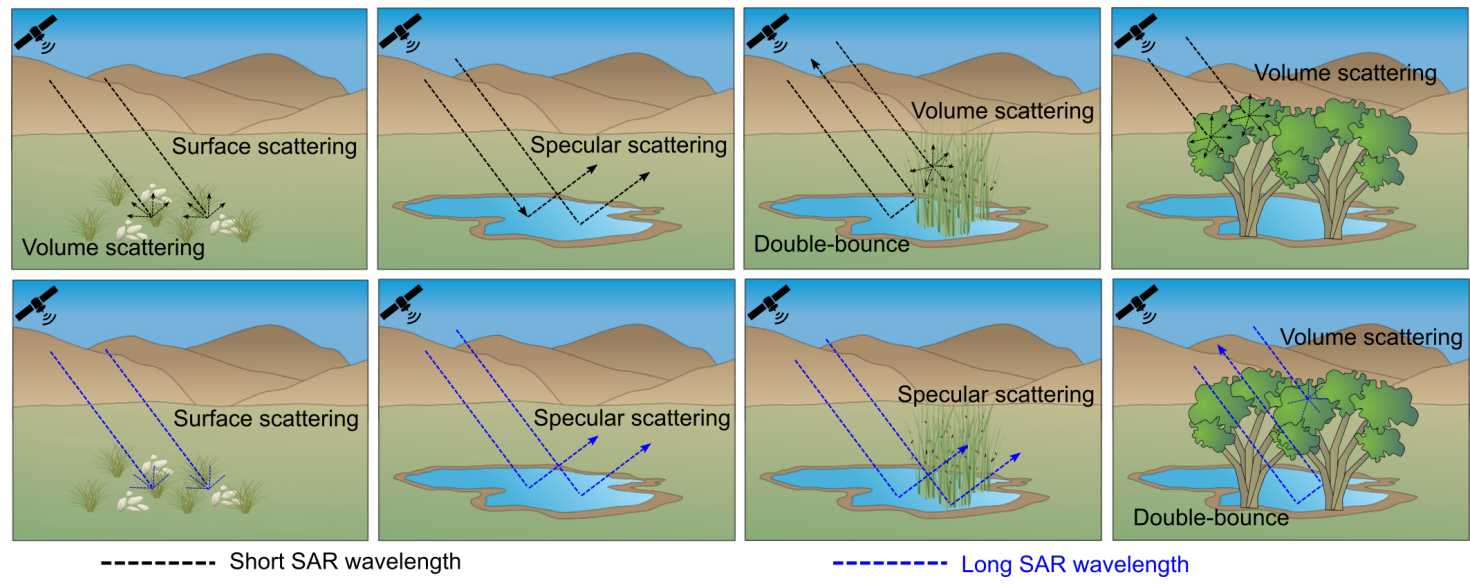

Figure 3. Simplified schematic illustration of the dominant backscatter mechanisms for short (e.g., X, $3.1 \mathrm{~cm}$ ) and long (e.g., $\mathrm{L}, 23.6 \mathrm{~cm}$ ) wavelengths for various surface cover conditions related to wetland.

\section{TerraSAR-X and Wetlands}

TerraSAR-X was launched into orbit on 15 June 2007, has been fully operational since January 2008, and is the first German operational radar satellite mission [62]. The X-band radar sensor offers a wide range of beam modes, allowing it to record images with different swath widths, resolutions, polarizations, and incidence angles. Using its active radar antenna, TerraSAR-X is able to produce image data ranging from medium-scale imaging in ScanSAR and StripMap mode to high-resolution small-scale application in the SpotLight mode, with a spatial resolution of down to one meter (see Figure 4), allowing for new research perspectives in various fields, including hydrology, geology, oceanography, or ecology [63].

Particularly in the field of wetlands, research requires the highest spatial resolution to characterize the small-scale heterogeneous nature of wetland ecosystems. Additionally, due to its repeat cycle of 11 days, TerraSAR-X provides the opportunity of acquiring high-resolution time-series of radar images. This holds the potential to strongly improve the accuracy of wetland assessments, in which data acquisition timing is a critical issue, given the significant temporal variability of most wetland types [34]. 

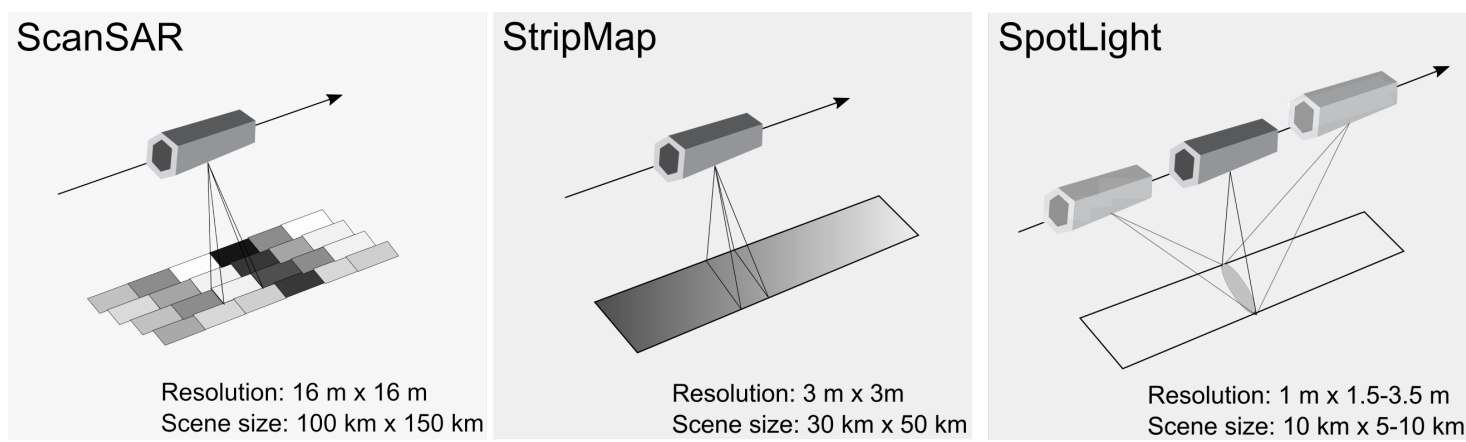

Figure 4. TerraSAR-X basic imaging modes and main configurations $[62,63]$.

\subsection{How Has TerraSAR-X Been Used in Wetland Studies?}

It is important to appreciate differences in these instrument specifications because the selection of optimal specifications must be tailored to different applications to help ensure project success. Each study design and research question related to wetlands requires particular image geometries, polarimetric information, and extent of data on spatial and temporal scale. The following subsections describe the different usage of TerraSAR-X images, focusing on sensor specifications such as imaging modes, polarization, incidence angle, and amount of data sets, acquisition, and the respective function of images used in wetland studies.

\subsubsection{Sensor Specifications}

The majority of the analyzed studies (21 from 32 articles, see Figure 5) used TerraSAR-X images in StripMap mode, which provides a good trade-off between resolution and coverage. As an advantage, even very small land cover patches can be detected in classification approaches to enable an accurate estimation of wetland extent in large heterogeneous areas. The SpotLight imaging mode was utilized in seven studies, indicating that the advantages of high spatial resolution data, especially for the classification of intertidal areas such as the detection of mussel beds, were investigated $[38,40]$. ScanSAR images with a wide area coverage and a reduced resolution were used least amongst the selected TerraSAR-X-related articles, and were mainly acquired for regional-scale analysis [64].

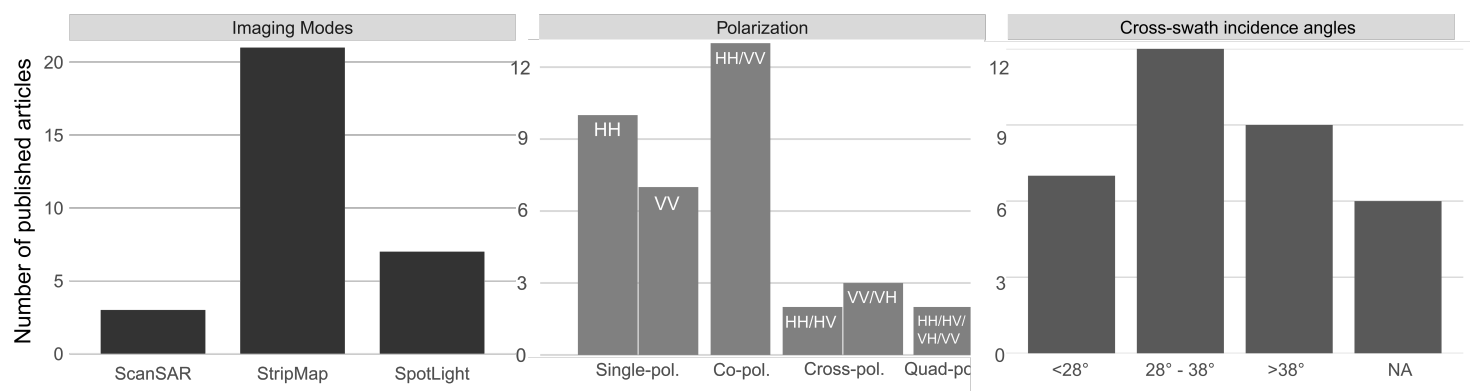

Figure 5. Sensor specifications (imaging modes, polarization, cross-swath incidence angles) of TerraSAR-X data for wetland studies.

The majority of all wetlands publications (20) used dual-polarized TerraSAR-X images, with emphasis on HH/VV co-polarizations. Wetlands in the form of flooded vegetation are expected to show a strong double-bounce backscattering. This mechanism can only be identified by analyzing dual (HH/VV, HH/VH, or VV/VH) or quad polarized (all four polarizations, quad-pol) datasets. Multi-polarized images enable the exploitation of polarimetric parameters as an additional input for wetland mapping $[31,65,66]$. The added value of multi-polarizations stands out in the distribution of polarizations used in TerraSAR-X-related wetland studies (see Figure 5). The enhanced backscatter 
interactions of the horizontally $(\mathrm{HH})$ with little increase in the vertically polarized (VV) between flooded surface and wetland vegetation allows the identification of inundation, and additionally ensures a stable phase relation [66,67]. Thus, the usage of co-polarized images (13) predominates within wetland studies. With respect to single-polarized data, HH (10) slightly outweighed VV (7) polarization. HH-polarized SAR data are less sensitive to wind-induced surface roughness in open water and show a stronger contrast between flooded and non-flooded areas, and were consequently favored over VV [68]. Quad-polarization data were least used (2), and play a minor role in wetland studies, since the quad-polarimetric mode was only a short-term experimental phase for TerraSAR-X and the availability of acquisitions is limited $[69,70]$. Still, exploiting quad-polarization parameters for wetland classification showed promising results for wetland mapping in the Biebrza Floodplain, Poland, compared to other sensors and polarizations [71]. Notably, 9 from 33 wetland studies used a combination of different polarizations for a comparative analysis of input parameters for wetland classification.

As already stated in the previous chapter, the incidence angle can have a significant effect on the radar signal related to wetland research. We categorized the incidence angles in three main categories according to their degrees across all swath modes: small (lower than 28 degrees); intermediate (between 28 and 38 degrees); and large (above 38 degrees). Six studies did not provide any information about the incidence angle. The majority of all publications (12) applied the intermediate incidence angle range, which is well-suited for land applications with no major relief. Studies using large (9) or small (8) incidence angles tend to be balanced.

However, in many research projects, the configuration used additionally depends on the frequency of the acquired mode, and thus does not necessarily constitute the usefulness of that particular sensor specification. This constrains a general comparison of sensor configurations in terms of their benefits.

\subsubsection{Usage of TerraSAR-X Data}

The number of TerraSAR-X acquisitions used for wetland studies differed depending on the extent of the study area and the analyzed time frame. Most studies (13) used between two and five images for wetland mapping. However, 11 articles utilized more than 20 TerraSAR-X images, most frequently for multi-temporal analyses. With a total of 143 scenes, the study of Da Lio et al. [44] used the highest number of TerraSAR-X acquisitions within a single study.

The majority of wetland articles (19 studies) exploited time-series of TerraSAR-X data (see Figure 6). Multi-temporal images are an ideal tool set for capturing changing wetland dynamics, classifying and differentiating seasonally dependent vegetation [67]. Given the high repetition time of TerraSAR-X (11 days), high-resolution time-series of images are potentially available for any desired region, in contrast to other high-resolution SAR sensors.

Often, TerraSAR-X acquisitions were combined or fused with other remote sensing sensors. Optical data from Landsat (seven articles) and very-high-resolution (VHR) optical sensors (six articles) were used most frequently as an additional source of information or for validation purposes (see Figure 6). Likewise, images from other radar sensors such as RADARSAT-2, ALOS-PALSAR (six articles each), and Sentinel-1 (three articles) found wide use.

Regarding the methods used in TerraSAR-X-based wetland studies, the direct analysis of backscatter intensity (amplitude) and the application of polarimetric SAR (PolSAR) were in balance (13 articles each, see Figure 6). On the one hand, the intensity of radar backscatter (amplitude) was frequently taken as an input parameter for wetland classification, in most cases by applying a certain threshold for class discrimination (e.g., [72]). On the other hand, multiple articles took advantage of PolSAR techniques as a sophisticated approach for discriminating different land cover and wetland types according to its respective dominant scattering mechanisms [46,73]. Interferometric SAR (InSAR) is another method applied on TerraSAR-X images (six articles). For wetland environments, it is mostly utilized to detect water-level changes or ground deformation processes due to a lowering groundwater table (e.g., [74]). 

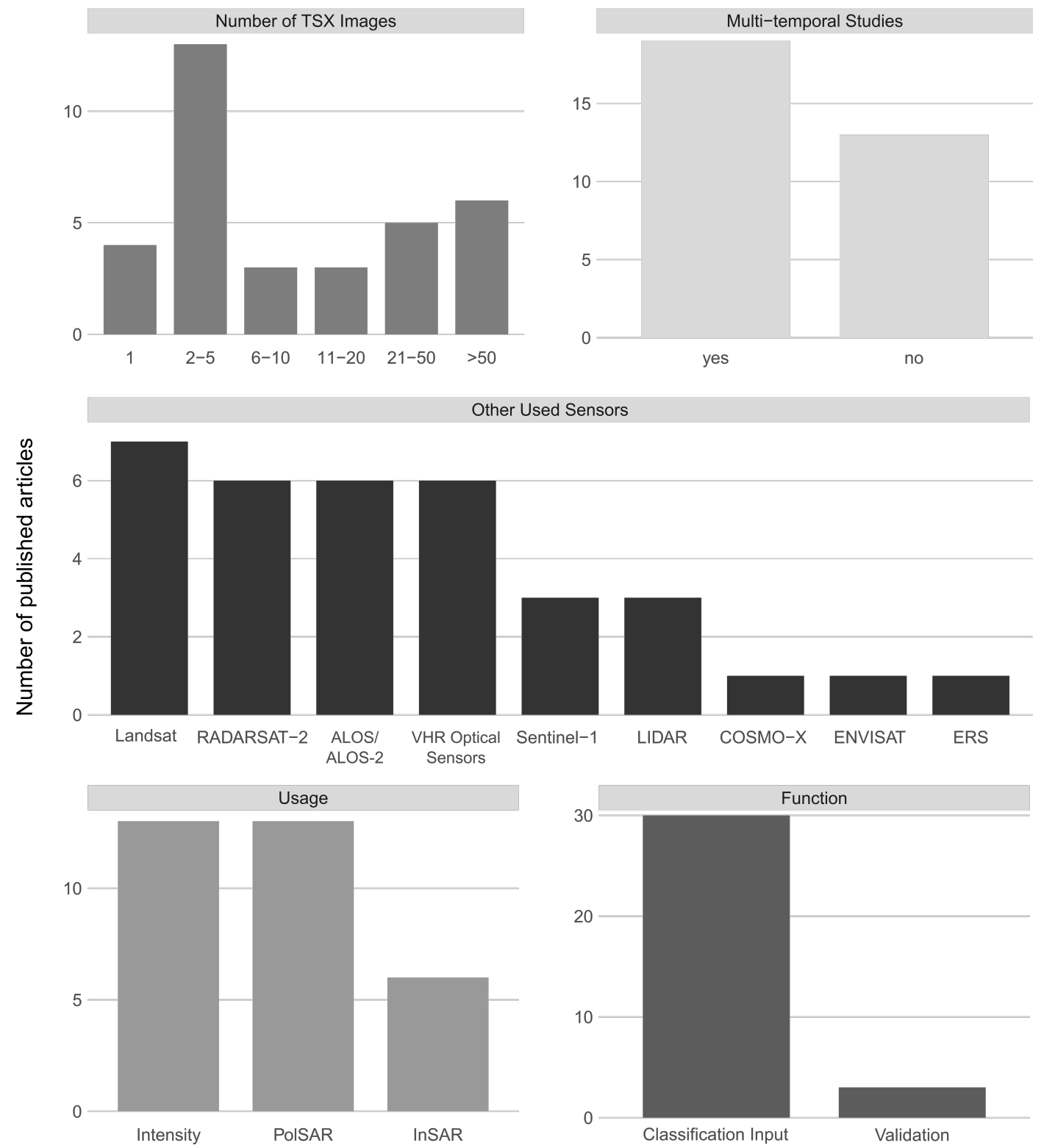

Figure 6. Usage of TerraSAR-X (TSX) data for wetland studies: Amount of images, multi-temporal analysis, other sensors combined, methodological approach, and function of the data. InSAR: interferometric SAR: PolSAR: polarimetric SAR.

Almost all of the selected wetland studies used TerraSAR-X images as a main input for land cover or wetland classification (30 articles). Only three papers utilized them as reference data for validation.

\subsection{Delineation and Characterization of Various Wetland Types}

As previously stated in Section 2, wetland ecosystems comprise spatially and temporally heterogeneous structures, which according to the Ramsar Classification Scheme can be categorized into marine, estuarine, lacustrine, riverine, and palustrine [36,37]. They share similar hydrologic, hydrogeomorphologic, chemical, or biological features. We classified the selected studies according to these generalized classes. The number of published articles ranked by wetland category is displayed in Figure 7. Some studies contained multiple wetland classes, which have been assigned to the predominant category within the study. Marine and estuarine ecosystems received the most scientific attention, with 11 and 10 published articles, respectively. There were only six and four TerraSAR-X articles incorporating the lacustrine and palustrine wetland classes, respectively. 


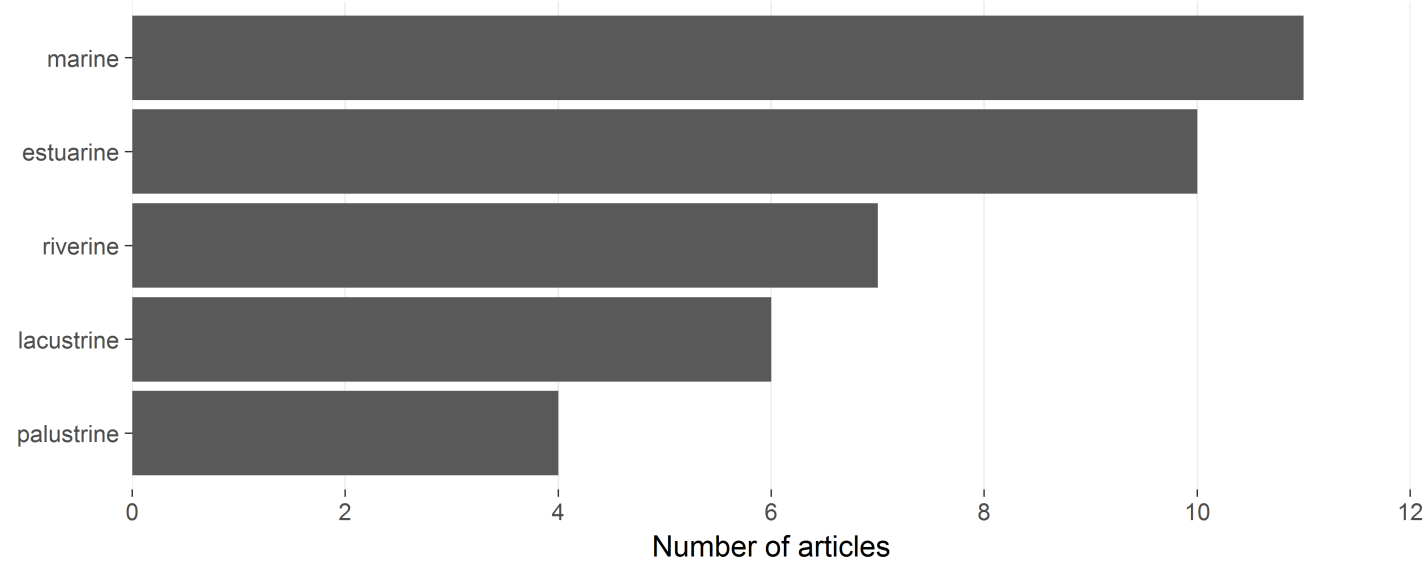

Figure 7. Number of studies categorized by wetland type.

\subsubsection{Palustrine Wetlands}

Palustrine ecosystems represent the "traditional" image of wetlands including marshes, swamps, and bogs. They comprise all non-tidal and non-riverine wetlands that are vegetated by trees, shrubs, or emergent herbaceous plants, as well as all tidal wetlands where the concentration of ocean-derived salts is less than $0.5 \mathrm{ppt}$ [75]. In the following, all published articles related to palustrine wetland ecosystems are introduced in chronological order.

The synergistic use of TerraSAR-X and optical Landsat ETM+ data for delineating heterogeneous landscape features in a cloud-prone area (Uganda) was demonstrated by the study of Otukei et al. [72]. The authors fused a single-polarized (HH) TerraSAR-X band and all spectral Landsat bands acquired in 2009 by applying high-pass filtering (HPF) and principal component analysis (PCA). The latter fusion technique was further divided into a PCA with band substitution and a wavelet transform. The mono-temporal classification was based on a $C 4.5$ decision tree to predict a total of 13 land cover classes, including 3 wetland classes. Accuracy assessment was performed using optical high-resolution IKONOS images. Overall, the PCA with wavelet transform showed highest accuracies reaching approximately $85 \%$, while the wetland classes ranged from $68 \%$ for degraded wetlands to $80 \%$ for papyrus vegetation. The authors suggested the exploration of object-based methods for further analysis.

A comparison of dense intra-annual time-series (from 2010) of high-resolution spatial data from multi-spectral RapidEye and HH-polarized TerraSAR-X data to classify various small-scale wetland vegetation habitats in Germany was conducted by Schuster et al. [76]. The high temporal resolution of the remote sensing data is able to identify different vegetation classes using the inherent phenological properties. In general, both sensors attained very high overall accuracies, greater than $90 \%$. TerraSAR-X time series showed better classification results particularly for Arrhenaterion elatioris, Solidago canadensis, and Phragmitetum australis. Due to their distinct and fast-growing vertical structure, these plant communities return a clear trajectory in TerraSAR's X-band. In contrast, the low structural growth of Caricion elatae and Calthion palustris resulted in lower accuracies compared to the optical data. In summary, this study demonstrated the reliable application of very high spatial and temporal resolution optical or X-band SAR data for a wide range of different grassland ecosystems.

Dabrowska-Zielinska et al. [64] explored the potential of interferometric Sentinel-1 data to assess carbon flux and soil moisture over the Biebrza Wetland in north-eastern Poland. In this context, three ScanSAR TerraSAR-X VV scenes combined with one Landsat 8 OLI acquisition served as classification input to delineate various wetland habitat types, such as reeds, sedge-moss, sedges, or grassland. The supervised maximum likelihood classification yielded accuracies of around $87 \%$. Furthermore, class-specific $\mathrm{CO}_{2}$ flux and soil moisture were modeled based on interferometric Sentinel-1 data. 
A multi-hierarchical classification framework for discriminating wetland types on the Avalon Peninsula (Canada) based on multi-polarization and multi-frequency SAR data was developed by Mahdianpari et al. [49]. They integrated single-polarized TerraSAR-X (HH), dual-polarized ALOS-PALSAR-2 (HH/HV), and quad-polarized RADARSAT-2 images. As a first step, a SAR backscatter analysis separated water from non-water classes (Level-I), followed by a more detailed Level-II classification, in which the water class was further divided into shallow and deep-water, and non-water separated into herbaceous and non-herbaceous vegetation classes. The final Level-III classification split the herbaceous class into bog, fen, and marsh classes. For the Level-II and Level-III classifications, different polarimetric features were extracted as input variables for the object-based random forest classification. These included covariance, coherency, Cloude-Pottier, Freeman-Durden, Yamaguchi decompositions, and Kennaugh matrices computed from dual- and quad-polarimetric SAR data, as well as the single-pol TerraSAR-X intensity. An overall accuracy of around $94 \%$ was yielded, whereas wetland classes reached $81 \%$. The detailed backscatter analysis revealed the highest backscatter values for $\mathrm{HH}$ polarized TerraSAR-X images. When comparing wavelengths, the X-band possessed higher backscatter for herbaceous classes, while L-band represented the higher backscatter in the swamp class.

\subsubsection{Lacustrine Wetlands}

Lacustrine wetlands are associated with lakes, ponds, and their margins. They are characterized by non-flowing water and non-saline conditions with a depth of more than $2 \mathrm{~m}$ at low water level [75]. They are dominated by open water areas and beds of submerged, floating, or non-persistent vegetation, and are usually lacking trees and shrubs. Edge vegetation includes tall reed-like plants, such as rush. Lakes can also be associated with peat. Shallower water bodies are assigned to the palustrine ecosystem. This subsection chronologically presents all articles dealing with lacustrine ecosystems.

The study of Regmi et al. [50] investigated the possible application of TerraSAR-X's X-band to determine the times where thermokarst lakes on the Alaska Arctic Coastal Plain drained in order to understand post-drainage succession. In addition, the Normalized Difference Vegetation Index (NDVI) derived from a multi-spectral Landsat-5 image was utilized to better interpret the backscatter signal and thus to identify major biophysical parameters. A total of six single-polarized TerraSAR-X HH (StripMap) images were acquired during the growing season in 2009 covering 14 thermokarst lakes, previously radio-carbon-dated by Jones et al. [77], with a drainage age ranging from 225 to around 9500 years BP. Younger drained lakes (1950-2010) were determined by aerial and satellite sensors. The authors performed regression analysis between SAR backscatter and the NDVI of all selected lakes, which were grouped into three temporal subsets ( $0-50$ years, 50-10,000 years, and 0-10,000 years). The regression analyses indicated a significant relationship between $X$-band backscatter/NDVI and drainage age for the long-term subsets $(0-10,000$ and 50-10,000). Surprisingly, no clear relationship was found for the modern 50 year time-scale. The study revealed an overall decreasing trend in backscatter and NDVI with increasing age of the the drained lake system, due to changing surface properties related to vegetation succession, soils, and hydrology.

Using TerraSAR-X time-series of 19 dual-polarized StripMap data, Heine et al. [70] identified reed belts of a lake in northeastern Germany and monitored their phenological changes. The authors calculated 16 different polarimetric indices based on HH/VV intensities serving a random forest classifier to delineate five major landscape features. Results showed that intensity difference HH-VV, the mean alpha scattering angle, intensity ratio $\mathrm{HH} / \mathrm{VV}$, and the coherence (phase) tend to be the most explaining variables for reed classification. The study also confirmed a better suitability of winter acquisitions to separate reed plants from other vegetation types due to an increase of double-bounce scattering when vegetation defoliates. In summer, volume scattering is the dominating scattering mechanism. The overall accuracy of all five classes reached more than $90 \%$, whereas reeds only achieved around 50\%. The authors suggest a denser temporal data stack to make use of the inherent and fast-changing phenology in order to improve the classification accuracy. 
Another study involving TerraSAR-X time-series was undertaken by Moser et al. [68]. They mapped the spatio-temporal dynamics of prevailing land cover types of the largest freshwater lake in Burkina Faso, Lac Bam. The dense dual-polarized HH-VV StripMap time-series data (21 images) were acquired between 2013 and 2014 covering both rainy and dry seasons. Apart from the frequently applied decomposition techniques developed by Cloude and Pottier [78] or Pauli [79], the normalized Kennaugh elements developed by Schmitt et al. [65] were chosen here as the preferred decomposition technique, as they can be applied on dual- and quad-polarized SAR data of any wavelength. The authors carried out two supervised classification approaches. In the first case, called the mono-temporal approach, four static land cover categories (including flooded vegetation) were defined, and every Kennaugh image was classified. The second or multi-temporal case included dynamic processes by defining change classes through visual inspection of very-high-resolution optical RapidEye data. The overall accuracy of dual-polarimetric SAR data reached 88.5\%, whereas a single-pol classification only using $\mathrm{K}_{0}$ showed lower accuracy $(82.2 \%)$. Overall, the static classes performed better than the dynamic ones. Flooded vegetation held class-specific accuracies ranging from 84.2 to $94.9 \%$. This study specifically demonstrated the out-performance of dual-pol SAR acquisitions in wetland mapping compared to single polarized imagery.

A data fusion approach combining the TerraSAR-X sensor, optical multi-spectral data and airborne laser scanning light detection and ranging (LIDAR) for surface water detection was conducted by Irwin et al. [53]. Five single-polarization HH SpotLight acquisitions from April to September 2016 were processed to create water masks for each time step. A gray level thresholding analysis revealed an intensity value of $-25 \mathrm{~dB}$ to clearly separate water from non-water areas. Based on the temporal complementary LIDAR and RapidEye datasets, individual water masks were created. To take advantage of each sensor's strength and compensate for the weaknesses of SAR, LIDAR, and optical systems, all water masks were combined into a fused water mask model. In doing so, the final fused model showed higher accuracies compared to the classification of the single-polarized TerraSAR-X water mask, which was $17-23 \%$ lower. The uncertainty of the final fusion water masks ranged between $4 \%$ and $9 \%$.

Interferometric synthetic aperture radar (InSAR) is one of the most popular techniques for measuring ground deformation and subsidence, which is often associated with changes in groundwater levels. Parker et al. [54] used Sentinel-1A (C-Band) to delineate ground displacements over a wetland area in the Perth Basin (Australia). In this study, TerraSAR-X InSAR time-series (21 acquisitions) served as an independent validation dataset together with a continuous GPS measurement. Both satellites are able to detect small-magnitude deformation, and showed close agreement between the vertical displacement and the measured GPS data. The average deviations for Sentinel-1A and TerraSAR-X are $9 \mathrm{~mm}$ and $5 \mathrm{~mm}$, respectively.

Ullmann et al. [73] characterized a heterogeneous tundra landscape with abundant thermokarst lakes and associated wetlands at the Tuktoyaktuk Peninsula in Canada. They calculated and compared several decomposition features of quad-, co-, and cross-polarized data acquired from different sensors, including X-band from TerraSAR-X, C-band (RADARSAT-2), and long-wave L-band from ALOS-PALSAR and ALOS-PALSAR-2. Shorter wavelength (X- and C-band) tend to be more efficient in separating wetland and tundra vegetation, while the L-band can better characterize bare ground classes. In general, the Kennaugh matrix decomposition [65] was found to be the most crucial variable for class discrimination, of which the intensity-based elements of the quad-polarized data offered the best separation. For the wetland class, best class-specific separability could be attributed to Kennaugh features of quad-polarized data (ALOS-PALSAR, RADARSAT-2) and dual- as well as cross-polarized data from TerraSAR-X. Correlation analyses also revealed high correlation between quad-polarized Kennaugh matrix elements $\left(\mathrm{K}_{0}, \mathrm{~K}_{1}, \mathrm{~K}_{3}, \mathrm{~K}_{4}, \mathrm{~K}_{7}\right)$ and dual-polarized elements, which could therefore be a substitute for those data. 


\subsubsection{Riverine Wetlands}

Riverine wetlands are associated with flowing water in rivers or streams and their morphology. The water levels and volumes can be highly variable from season to season. Wetlands may contain flowing water permanently or may remain periodically dry for long intervals. As a result, riverine wetland ecosystems support a wide range of variable species. A total of six articles related to riverine wetlands have been published (Figure 7).

The study of Englhart et al. [52] explored the capabilities of X- (TerraSAR-X) and L-band (ALOS-PALSAR) to estimate aboveground biomass (AGB) in intact and degraded swamp forests in Borneo (Indonesia). Based on full-waveform LIDAR combined with field inventory data, an AGB model (multiple linear regression) was developed, which served as the reference data set. TerraSAR-X images acquired in the ScanSAR mode at VV polarization were considered. The long-wave SAR counterpart L-band ALOS-PALSAR was acquired at HH/HV polarization. The LIDAR-based estimated AGB were used to find the relationship between biomass and SAR backscatter signal and were subsequently upscaled across a larger area to provide multi-temporal information about various forest types and their condition. Results revealed that ALOS-PALSAR L-band backscatter is more sensitive to high biomass conditions (more than $100 \mathrm{t} / \mathrm{ha}$ ), whereas TerraSAR-X performed better in low biomass ranges depicting degraded swamp forests. The most reliable results were achieved with the combined $\mathrm{X}$ - and L-band model using multi-temporal information. The overall model achieved accuracies of $53 \%$. This work again highlighted the beneficial use of multi-frequent SAR information to delineate intact swamp forests with L-band, whereas X-band was more explanatory for degraded ecosystems.

Two studies from Betbeder et al. [31,80] presented another multi-temporal approach for wetland mapping based on TerraSAR-X time-series. In both studies, the authors utilized dual-co-polarized $\mathrm{HH} / \mathrm{VV}$ images to calculate one polarimetric parameter, the Shannon entropy, and two intensity parameters to characterize wetland vegetation from six [31] and eight [80] images, respectively. The latter study also determined the optimal minimum number of required SAR images, the best timing of acquisitions, as well as best parameter combinations to achieve sufficient classification accuracy. Both chose support vector machine techniques for the final classification, attaining very high overall accuracies of $84 \%$ in the first study [31] and even $94 \%$ in the second one [80]. They also revealed the importance of polarimetric features for mapping wetland formations, rather than only using backscattering coefficients. Betbeder et al. [80] also indicated late winter (February), spring (April and May), and the beginning of summer (June and July) as the most relevant periods for wetland mapping covering the inherent phenological trajectories of each land cover class. Sensitivity analysis revealed that five TerraSAR-X acquisitions saturated almost at the final classification accuracy level (95\%), hence being sufficient to balance the trade-off between the number of acquisitions and overall accuracy.

The effect of inundated vegetation on HH/VV backscatter and phase difference for TerraSAR's X-band was examined by Zalite et al. [81]. The authors ordered two TerraSAR-X StripMaps at HH/VV polarization, representing both flooded and non-flooded conditions, covering the Soomaa National Park located in south-western Estonia. This landscape encompasses two transiting rivers with adjacent floodplains and forests. In this study, coniferous and deciduous forest stands with different tree heights were investigated. As a first step, complex $\mathrm{HH} / \mathrm{VV}$ images were calculated by subtracting the VV from the $\mathrm{HH}$ channel to gain information about backscatter mechanism (e.g., double-bounce) and calibrated to $\sigma^{0}$. To cover the prevailing land cover characteristics, 12 patches of $115 \mathrm{~m} \times 115 \mathrm{~m}$ were selected. For each patch, the differences of backscatter and phase between the two time-steps were calculated and compared. Results revealed an increase in $\mathrm{HH}$ backscatter from 2.3 to $8.2 \mathrm{~dB}$ for the complex HH/VV and from 3 to $9.8 \mathrm{~dB}$ over all patches, when vegetation became inundated. The study also showed that the dual-co-polarization $\mathrm{HH} / \mathrm{VV}$ channel separated flooded from non-flooded vegetation better than the single-polarized band. The considerable increase in phase shift suggests a stronger double-bounce backscatter mechanism. When comparing evergreen and deciduous tree species (leaf-off season), the latter tend to have higher phase differences due to stronger double-bounce backscatter. 
A multi-frequent backscatter analysis for mapping and monitoring wetland extent and inundation pattern was conducted by Mitchell et al. [67] in the Macquarie River Catchment in north-central Australia. This area consists of various riverine wetland types, including numerous herbaceous and woody vegetation communities. The authors acquired L-band ALOS-PALSAR and TerraSAR-X time-series data during dry, wet, and transitional wetland conditions. However, two TerraSAR-X cross-polarized $\mathrm{HH}$ and HV polarized StripMap scenes were exclusively applied on the transitional phase. For water body detection, only the longwave L-band data was used. The synergy of both sensors was explored for discriminating different vegetation communities. Two statistical approaches were tested. In the first, the mean radar spectra for each land cover class were calculated and spectrally separated by using two separability measures (Jeffries-Matusita and the Transformed Divergence). The second approach was only applied to the ALOS-PALSAR data. A canonical variate analysis (CVA) was used to determine the best single band and band combination for wetland discrimination. The results of this study once again showed the improved wetland discrimination when multi-frequency SAR data are used in a complex environment. Due to the occurrence of woody vegetation, L-band performed better in mapping sub-canopy inundation, whereas the X-band was able to detect flushes in growth of vegetation in response to higher soil moisture from flooding.

A very recent study was published by Mleczko and Mrôz [71] investigating the desiccation of wetlands and biodiversity loss in the floodplains of the Biebrza River in Poland. This comparative study applied C-band from Sentinel-1 and X-band from TerraSAR-X to map different vegetation types (wet grasslands, reed, flooded deciduous forest) and flooding conditions (permanent and temporarily flooded). The six TerraSAR-X images were acquired in quad-pol during the quad-polarimetric experimental mode [69]. For the wetland classification, $\sigma^{0}$, coherence, Shannon entropy, and the Yamaguchi decomposition parameter (quad-pol data only) were computed. The best classification results were achieved with the inclusion of the TerraSAR-X quad-pol data with overall accuracies of 79\%, whereas the Sentinel- 1 time-series alone resulted in $65 \%$. Comparing the different TerraSAR-X polarimetric modes, the dual-polarized dataset performed with an overall accuracy of $76 \%$ in a similar range as the quad-pol accuracies (79\%). As descriptor for characterizing wetland types, the Shannon entropy yielded lower accuracies ranging from $47 \%$ to $58 \%$. The integration of the interferometric coherence in the classification scheme tends to have less importance in distinguishing between wetland classes.

\subsubsection{Estuarine Wetlands}

Estuaries are located in marine deltas, where a river meets the sea. Lying along an estuary with a mix of saltwater coming from the sea and freshwater from the river and being subject to tidal flooding, these wetlands are associated with estuarine marshes and salt marshes, intertidal flats, swamps, and mangrove forests [82]. Estuarine wetlands are valuable coastal ecosystems that not only provide flood control and shoreline stabilization, but also offer an important habitat for juvenile marine organisms and migrating birds. They support a wide range of threatened plant species. Regarding the selected wetland studies, estuarine wetlands cannot be easily distinguished from marine wetland applications, since both wetland types often coincide. In the following, TerraSAR-X-related studies primarily dealing with estuarine wetlands are presented.

Hong et al. [45] examined water-level changes over South Florida's Everglades wetlands during an eight month period in 2008 based on the interferometric analysis of dual-polarized TerraSAR-X observations. Interferometric coherence of all four polarizations was evaluated in order to determine the dominant scattering mechanisms in each of the different wetland environments within the study area, containing both managed and natural flow fresh- and salt-water wetlands. The authors revealed high coherence in all polarizations, with the highest response in HH. Fringe patterns of interferograms derived from multi-polarized data did not differ significantly among the polarization types, indicating that the phase information reflects water-level changes, and volume scattering was ruled out as the dominant scattering mechanism. Overall, the applied wetland InSAR approach worked well with X-band TerraSAR-X data. 
In 2015, Hong et al. [46] published another study related to the Florida Everglades. The authors examined the applicability of TerraSAR-X quad-polarization data for wetland vegetation mapping. In doing so, different scattering mechanisms were extracted using both Hong \& Wdowinsky four-component decomposition as well as Yamaguchi's decomposition, which were utilized for classifying vegetation types with an object-based image analysis approach. High-resolution optical RapidEye imagery was used for validation. Good accuracies of over $93 \%$ were achieved by classifying with the SAR image features. Overall, quad-pol X-band PolSAR products performed as good indicators for wetland vegetation mapping, especially for mangrove forests. According to the authors, the availability of operational X-band quad-pol images remains as one of the main limitations of PolSAR-based wetland classification.

With the aim of evaluating the potential of dual-polarized TerraSAR-X data for mapping different peatland forests, Wijaya et al. [51] used $\mathrm{H} / \alpha / \mathrm{A}$ (entropy/alpha/anisotropy) decomposition of the covariance matrix and canonical discrimination analysis for determining the importance of SAR parameters for peatland discrimination in tropical swamp and mangrove forests within the Tanjung Putig National Park in Central Kalimantan, Indonesia. Although anisotropy and entropy proved to be more important than other SAR features for peatland classification, X-band SAR alone could not provide satisfactory results. The distinction of shallow and deep peat soils under relatively closed canopies remains challenging. However, a supervised maximum likelihood classification based on TerraSAR-X fused with optical Landsat ETM data yielded up to $87 \%$ accuracy.

Lagomasino et al. [47] compared different remote sensing techniques to measure mangrove forest canopy heights in the Zambezi River delta from airborne and space-borne platforms using LIDAR, stereophotogrammetry, and radar interferometry. The authors derived four canopy height models based on VHR stereophotogrammetry from WorldView-1, TerraSAR-X add-on for Digital Elevation Measurements (TanDEM-X), and the Shuttle Radar Topography Mission (SRTM). For this, the spatiotemporal variability between the sensors as well as a comparison of model efficiency for canopy height models were of primary importance. SRTM overlooks fine-scale forest canopy and poorly represents the top of the canopy, but provides temporal stability and is an accurate indicator for the mean height distribution of mature, intact mangrove forests. Taller canopies are accurately represented by high-resolution TanDEM-X models, but shorter canopies are not estimated in detail. Lastly, VHR canopy height models derived from stereophotogrammetry showed good accordance with LIDAR as "the gold standard" of mangrove forest canopy models.

Furthermore, Ullmann et al. [83] applied a two-component polarimetric decomposition technique for quad-pol RADARSAT-2 (C-band) and dual-co-pol HH/VV TerraSAR-X (X-band) in order to investigate the role of volume scattering from vegetation in a tundra environment across the Mackenzie Delta region in Canada. The approach decomposed total backscatter into surface and double-bounce scattering, and was compared to a three-component decomposition (quad-pol RADARSAT-2). The revealed PolSAR features were analyzed for each land cover class and correlated with each other based on scattering characteristics derived from in-situ ground truth data on land cover. Generally, little influence of volume scattering was revealed for land cover classes of low vegetation height, whereas wetland vegetation showed a high degree of volume scattering. The quad-pol RADARSAT-2 data provided the best separation of tundra land cover classes. Nevertheless, wetlands showed a clear position in both the C- and the X-band HH/VV-PolSAR feature spaces, indicating an accurate classification.

\subsubsection{Marine Wetlands}

Marine wetlands are located along coasts, in offshore reefs, dune hollows, or sand plains. They include rocky shores, coastal lagoons, coral reefs, and subtidal seagrass beds with a depth of up to six meters (at low tide). Influenced by saltwater, marine wetlands are exposed to ocean currents, waves, and tides. Further, they are dominated by saltwater-tolerant plants and provide not only an essential nursery and feeding space for a wide range of fish and sea turtles, and also represent 
a valuable habitat for migratory birds [56,82]. Related to TerraSAR-X, 11 studies with a focus on marine wetlands have been released, indicating the most-studied wetland type of our review.

With the aim of investigating the extent of submarine groundwater discharge (SGD) to large tidal flats along the Korean coast, Kim et al. [41] compared polarimetric backscattering coefficients obtained from both TerraSAR-X (X-band) and RADARSAT-2 (C-band) data with theoretical scattering models to detect water puddles. Based on in-situ measurements of surface roughness, soil moisture, and water salinity, two different scattering models—an updated integral equation model (IEM) and Oh's empirical model-were applied. Compared to the models, the SAR data showed lower backscattering over areas with water puddles. The authors revealed that both X- and C-band SAR are suitable tools for identifying water puddles in tidal flats. Eventually, these puddles can be associated with SGD according to their shape and location.

Another study dedicated to Korean tidal flats was published by Lee et al. [84], who used a backscattering analysis of 16 TerraSAR-X images, $\mathrm{HH}$ single, and VH/VV dual-cross polarizations for mapping halophytes of the Ganghwa tidal flat. Based on a decision tree classifier, a rule-based salt marsh mapping approach was designed in order to examine the ecological status, distribution changes, and optimum season for the mapping of halophytes. Winter was revealed as the best season for distinction between an annual plant, Suaeda japonica, and a typical perennial salt marsh, Phragmites australis, based on $\mathrm{HH}$ polarization backscatter. It was shown that TerraSAR-X is an effective instrument for mapping and monitoring seasonal variations of halophyte species in tidal flats.

A PolSAR-based land cover classification of an arctic tundra environment on Richards Island, Canada, was carried out by the authors of Ullmann et al. [85]. Here, a combination of dual-co-polarized TerraSAR-X (HH/VV), quad-polarized RADARSAT-2, and multispectral Landsat 8 OLI data was used for unsupervised and supervised classification of tundra land cover types. In-situ measurements and high-resolution aerial images were obtained during field campaigns, and served as reference data. The study did not exclusively focus on marine wetlands. However, a large part of the coastal wetlands was located along the shore and was shaped by an ocean setting. It was shown that combination of optical data with PolSAR features (entropy/alpha, Yamaguchi, two-component decomposition) significantly improved the classification results. Decomposition features of the dual and quad-polarized data showed a high sensitivity for double-bounce backscattering in wetland areas.

Several studies investigating intertidal flats have been published by Gade et al. (2014) [38], Jung et al. [42], and Gade et al. [39]. The first study of Gade et al. [38] revealed the high potential of SAR to complement and improve the monitoring of intertidal flats in the German Wadden Sea. For this, multiple SAR sensors including ALOS-PALSAR (L-band), ERS-1/2, RADARSAT-2, ENVISAT ASAR (C-band each), and TerraSAR-X (X-band) were utilized in order to detect benthic fauna such as mussel or oyster beds based on surface roughness parameters. Here, single-sensor performance was compared with multiple-sensor performance. As a result, statistical analysis of the multi-temporal TerraSAR-X data significantly improved the classification of mussel beds through a synergistic monitoring approach.

Jung et al. [42] also published a multi-sensor methodology for classifying intertidal areas in the Wadden Sea. Therefore, RapidEye and TerraSAR-X satellite data were combined. A hierarchical decision-tree classifier was applied to firstly separate water from tidal flat areas and secondly delineate the shellfish beds based on TerraSAR-X-derived textural features and morphological filters. Thirdly, vegetation was classified by means of a vegetation index and object-based feature extraction. The authors highlighted the great value of TerraSAR-X data for a detailed fish bed classification that reached an overall accuracy of $98 \%$. For this purpose, the usage of high-resolution radar sensors was regarded as indispensable.

A further study related to intertidal flats in the German Wadden Sea was published by Gade et al. (2016) [40], who utilized combined pairs of single-polarized (VV) TerraSAR-X and RADARSAT-2 as well as HH and VV-polarized TerraSAR-X images between 2008 and 2013 in order to image sediments, macrophytes, and mussels. The focus was laid on the SAR-based detection of 
morphological changes and bivalve beds of dry-fallen intertidal flats in order to improve existing classification systems. The results demonstrated that multi-temporal SAR imagery was a valuable input for classification due to its strong backscatter in bivalve beds. In particular, the polarization coefficient of SAR data based on both co-polarizations allowed the detection of mussel or oyster habitats. Further, with additional information about the water level available, multi-temporal and multi-frequency SAR proved to be a useful instrument for a change detection of intertidal flats.

Another more recent publication with regard to tidal flats on the German North Sea coast was released by Gade et al. [39] in 2018. The authors investigated the influence of imaging geometry and environmental parameters such as wind speed, water level, and vegetation period on the radar backscatter from exposed tidal flats using RADARSAT- 2 and TerraSAR-X single- and dual-co-polarized SAR images. Further, TerraSAR-X images were utilized for polarimetric analyses (PolSAR) based on the decomposition of the Kennaugh matrix. As a result, VV-polarized TerraSAR-X data was most sensitive to surface roughness as one of the most important environmental influencing factors. Other essential variables shaping the radar return are the local incidence angle depending on local topography, SAR look angle, and direction. Water-level history (e.g., low or high tide, level minimum at low tide) was also considered important for the backscatter intensity. Altogether, the potential of polarimetric decomposition for identifying surface types of intertidal flats was confirmed.

With the objective of investigating the linkage of surge extent and persistence after Hurricane Sandy landfall and condition change of coastal marshes along the New Jersey Atlantic coast, Rangoonwala et al. [86] used SAR time-series for surge mapping and optical satellite images for assessing changes in marsh condition. With a combination of TerraSAR-X and COSMO-SkyMed SAR data (HH polarization), the spatial and temporal extent of post-hurricane flooding in back-barrier lagoon marshes could be captured based on relative horizontal backscatter attenuation. Here, the ability of X-band to perceive marsh flooding at all depths was exploited. Linked with an analysis of marsh condition based on optical sensors (SPOT, MODIS), high surge-related marsh impacts in back-barrier lagoons north of the hurricane landfall track could be identified.

Recently in 2018, Da Lio et al. [44] presented an advanced persistent scatterer interferometry (PSI) technique on a 5-year long stack of TerraSAR-X acquisitions of the Venice Lagoon salt marshes for quantifying land subsidence between 2008 and 2013. Thousands of measurable persistent targets could be identified due to the short revisiting time of 11 days and the high spatial resolution of $3 \mathrm{~m}$. By integrating the SAR resolution with ground-based multi-depth displacement records, a quantitative conceptual model of salt marsh vertical dynamics could be established. Results showed a different subsidence behavior between natural and man-made salt marshes based on soil consolidation stages. Overall, the high heterogeneity of the superficial-subsoil dynamics were revealed, mirroring the diverse bio-morphological and geological setting at the salt marsh-scale.

\section{Conclusions}

This review demonstrates the wide-ranging application of TerraSAR-X data regarding mapping various types of wetlands, sensor specifications, temporal and spatial scales, as well as the applied methodology. Notably, marine and estuarine wetlands were amongst the most studied wetland types within the selected studies. In this context, the benefit of a synergy between the ability of X-band radar to capture non-vegetated or low herbaceous wetland vegetation along the coast without penetrating the ground surface and the high spatial and temporal resolution provided by TerraSAR-X has been utilized in many scientific publications. Furthermore, the distribution of wetland-related studies across the globe indicates an increased use of TerraSAR-X in cloud-prone areas, which mirrors the penetration of clouds as one of the main advantages of radar-based applications. Dual-polarized data were the most used among the selected studies, showing a peak in HH/VV co-polarization based on the strong double-bounce backscattering signal from flooded vegetation as well as the possibility of exploiting polarimetric parameters. In the case of the single-polarization data, $\mathrm{HH}$ was preferred 
over VV. Few studies acquired TerraSAR-X images during the experimental qual-polarization phase, providing promising results.

In this review, it was shown that polarimetric decomposition is a frequently applied technique for revealing the physical characterizations of the scattering scenario and the involved scatterers, and thus allows a more detailed view of the complex wetland environments. In general, PolSAR is a rapidly growing research field and, especially when combined with X-band radar, provides valuable information for wetland analyses due to the dominant double-bounce/surface scattering mechanisms to discriminate between different wetland characteristics. However, the limited availability of quad-pol data restricts its wider usage with TerraSAR-X. The high amount of wetland studies applying multi-temporal analyses indicates that the short revisiting time of TerraSAR-X (11 days) is an advantage of time-series analysis, which can provide crucial information about the seasonality of vegetation in wetland areas or tidal dynamics. However, the selection of the optimal timing is more important than the amount of data. Throughout all studies, results reveal that single-date acquisitions are not adequate for mapping wetland accurately.

Finally, the strengths of TerraSAR-X for wetland assessments lie in its high sensitivity to soil moisture and surface roughness on low-biomass surfaces. In particular, a good performance of TerraSAR-X for mapping salt marshes, including fish or mussel bed classification, as well as the depiction of degraded swamp forests and herbaceous vegetation, was highlighted in the reviewed studies. With respect to multi-temporal analyses, vegetation species showing fast growing vertical structures could be best distinguished by using X-band. However, the usage of TerraSAR-X data for areas with high-biomass conditions such as swamp forests with dense canopies showed limitations. Here, a better performance of L-band radar was discovered in several studies. On that basis, the combined usage of TerraSAR-X with other sensors yielded promising results for wetland mapping.

However, while SAR can improve the accuracy of wetland classifications in inundated areas, the partially limited availability and often high cost of radar imagery still limits its broader use [58]. Despite being free of charge for scientific and non-commercial users, the access to TerraSAR-X products is not straightforward. As a first step, data need to be ordered via a detailed science proposal describing research objectives, work plan, data requirements, and detailed information about the "scientific use" criterion. Each proposal is evaluated by a scientific and technical committee, which judge the scientific priority. If accepted, the data will be delivered electronically. However, depending on the project, commercial users sometimes receive higher priority, conflicting with orders from scientific users, which could result in a reduction of the data or even in a complete rejection. This may change in the near future due to transitions in data policies, indicating a trend towards freely available remote sensing data. Moreover, the synergistic use of different SAR data (e.g., TerraSAR-X with L-band radar sensors such as ALOS-PALSAR-2) is a promising approach in which both the advantage of high-resolution X-band radar for observing herbaceous wetland vegetation and the suitability of L-band radar to map forested wetlands by penetrating canopies are combined. Further, data fusion of TerraSAR-X with high-resolution optical data (e.g., RapidEye) proved to be extremely valuable for a detailed wetland classification, as high-resolution SAR data might be influenced by speckle noise, which degrades the true spatial resolution. In the future, multi-sensor approaches may become increasingly important for wetland assessment due to the growing availability of different sensors with the advantage of complementing each other.

Author Contributions: C.W. and K.W. developed the concept of this study, reviewed the literature, and wrote the majority of this paper. C.W. designed and prepared all figures. A.W. and A.R. provided written input and feedback on the content of this manuscript during the initial preparation and revision.

Funding: The TanDEM-X project is partly funded by the German Federal Ministry for Economics Affairs and Energy (Förderkennzeichen 50 EE 1035).

Acknowledgments: The authors would like to express their gratitudes to Isabel Georg for reviewing the English language.

Conflicts of Interest: The authors declare no conflict of interest. 


\section{Appendix A}

Table A1. Summary of all considered studies in this review using TerraSAR-X data in the domain of wetland research (in chronological order).

\begin{tabular}{|c|c|c|c|}
\hline Study (Year Published) & Study Area (Country) & Wetland Type & Research Objectives \\
\hline Da Lio et al. (2018) [44] & Venice Laggon (Italy) & marine, estuarine & land subsidence \\
\hline Gade et al. (2018) [39] & Wadden Sea (Germany) & marine & monitoring tidal flats \\
\hline Mleczko et al. (2018) [71] & Biebrza Valley (Poland) & riverine & wetland classification \\
\hline Irwin et al. (2018) [53] & Ontario (Canada) & lacustrine & wetland classification \\
\hline Mahdianpari et al. (2017) [49] & Avalon Peninsula (Canada) & palustrine & wetland classification \\
\hline Parker et al. (2017) [54] & Perth Basin (Australia) & lacustrine & land subsidence \\
\hline Ullmann et al. (2017) [73] & Tuktoyaktuk Peninsula (Canada) & lacustrine & tundra classification \\
\hline Zhou et al. (2017) [87] & Eastern Beijing Plain (China) & palustrine & land subsidence \\
\hline Dabrowska-Zielinska et al. (2016) [64] & Biebrza Valley (Poland) & palustrine, riverine & carbon fluxes \\
\hline Gade et al. (2016) [40] & North Sea (Germany) & marine & detection of bivalve beds \\
\hline Heine et al. (2016) [70] & Lake Fürstenseer (Germany) & lacustrine & reed classification \\
\hline Lagomasino et al. (2016) [47] & Zambezi River Shed (Mozambique) & estuarine & mangrove height classification \\
\hline Moser et al. (2016) [68] & Lac Bam (Burkina Faso) & lacustrine & wetland classification \\
\hline Ullmann et al. (2016) [73] & Mackenzie Delta (Canada) & esturine & wetland classification \\
\hline Rangoonwala et al. (2016) [86] & New Yersey Bay (USA) & marine, esturine & coastal wetland classification \\
\hline Betbeder et al. (2015) [80] & Mont-Saint-Michel (France) & riverine & wetland classification \\
\hline Jung et al. (2015) [42] & Norderney (Germany) & marine & tidal flats classification \\
\hline Mitchell et al. (2015) [67] & Macqarie Marshes (Australia) & riverine & wetland classification \\
\hline Hong et al. (2015) [46] & Florida Everglades (USA) & estuarine & wetland classification \\
\hline Morishita et al. (2015) [48] & Delft (Netherlands) & palustrine & peatland classification \\
\hline Schuster et al. (2015) [76] & Döberitzer Heide (Germany) & palustrine & wetland classification \\
\hline Otukei et al. (2015) [76] & Bwindi (Uganda) & palustrine & wetland classification \\
\hline Ullmann et al. (2014) [85] & Richard Island (Canada) & marine, estuarine & wetland classification \\
\hline Betbeder et al. (2014) [31] & Mont-Saint-Michel (France) & riverine & wetland classification \\
\hline Gade et al. (2014) [38] & North Sea (Germany) & marine & intertidal flats classification \\
\hline Zalite et al. (2014) [81] & Soomaa National Park (Estonia) & riverine & wetland characterization \\
\hline Lee et al. (2012) [84] & Ganghwa (Korea) & marine, estuarine & tidal flats classification \\
\hline Regmi et al. (2012) [50] & Seward Peninsula (USA) & lacustrine & peat age classification \\
\hline Kim et al. (2011) [41] & Namyang Bay (Korea) & marine & tidal flats classification \\
\hline Englhart et al. (2011) [52] & River Sebangau (Borneo) & riverine & swamp forest classification \\
\hline Hong et al. (2010) [45] & Everglades (USA) & riverine & mangrove classification \\
\hline Wijaya et al. (2010) [51] & Southern Kalimantan (Borneo) & riverine & swamp forest classification \\
\hline
\end{tabular}

\section{References}

1. Costanza, R.; d'Arge, R.; de Groot, R.; Farber, S.; Grasso, M.; Hannon, B.; Limburg, K.; Naeem, S.; O’Neill, R.V.; Paruelo, J.; et al. The value of the world's ecosystem services and natural capital. Nature 1997, $387,253$. [CrossRef]

2. Assessment, Millennium Ecosystem. Ecosystems and Human Well-Being: General Synthesis; Island Press: Washington, DC, USA, 2005.

3. Mitsch, W.J.; Bernal, B.; Hernandez, M.E. Ecosystem services of wetlands. Int. J. Biodivers. Sci. Ecosyst. Serv. Manag. 2015, 11, 1-4. [CrossRef]

4. Sharma, B.; Rasul, G.; Chettri, N. The economic value of wetland ecosystem services: Evidence from the Koshi Tappu Wildlife Reserve, Nepal. Ecosyst. Serv. 2015, 12, 84-93. [CrossRef]

5. Dodds, W.K.; Wilson, K.C.; Rehmeier, R.L.; Knight, G.L.; Wiggam, S.; Falke, J.A.; Dalgleish, H.J.; Bertrand, K.N. Comparing ecosystem goods and services provided by restored and native lands. BioScience 2008, 58, 837-845.[CrossRef]

6. Erwin, K.L. Wetlands and global climate change: The role of wetland restoration in a changing world. Wetl. Ecol. Manag. 2008, 17, 71. [CrossRef]

7. Shepard, C.C.; Crain, C.M.; Beck, M.W. The protective role of coastal marshes: A systematic review and meta-analysis. PLoS ONE 2011, 6, e27374. [CrossRef] [PubMed]

8. IPCC. Summary for Policymakers. In Climate Change 2013: The Physical Science Basis. Contribution of Working Group I to the Fifth Assessment Report of the Intergovernmental Panel on Climate Change; Stocker, T., Qin, D., Plattner, G.K., Tignor, M., Allen, S., Boschung, J., Nauels, A., Xia, Y., Bex, V., Midgley, P., Eds.; Book Section SPM; Cambridge University Press: Cambridge, UK; New York, NY, USA, 2013; pp. 1-30.

9. Mitsch, W.J.; Bernal, B.; Nahlik, A.M.; Mander, Ü.; Zhang, L.; Anderson, C.J.; Jørgensen, S.E.; Brix, H. Wetlands, carbon, and climate change. Landsc. Ecol. 2013, 28, 583-597. [CrossRef] 
10. Hu, S.; Niu, Z.; Chen, Y.; Li, L.; Zhang, H. Global wetlands: Potential distribution, wetland loss, and status. Sci. Total Environ. 2017, 586, 319-327. [CrossRef] [PubMed]

11. Davidson, N.C. How much wetland has the world lost? Long-term and recent trends in global wetland area. Mar. Freshw. Res. 2014, 65, 934-941. [CrossRef]

12. Foley, J.A.; DeFries, R.; Asner, G.P.; Barford, C.; Bonan, G.; Carpenter, S.R.; Chapin, F.S.; Coe, M.T.; Daily, G.C.; Gibbs, H.K.; et al. Global consequences of land use. science 2005, 309, 570-574. [CrossRef] [PubMed]

13. Nagendra, H.; Lucas, R.; Honrado, J.P.; Jongman, R.H.G.; Tarantino, C.; Adamo, M.; Mairota, P. Remote sensing for conservation monitoring: Assessing protected areas, habitat extent, habitat condition, species diversity, and threats. Ecol. Indic. 2013, 33, 45-59. [CrossRef]

14. Kuenzer, C.; Ottinger, M.; Wegmann, M.; Guo, H.; Wang, C.; Zhang, J.; Dech, S.; Wikelski, M. Earth observation satellite sensors for biodiversity monitoring: Potentials and bottlenecks. Int. J. Remote Sens. 2014, 35, 6599-6647. [CrossRef]

15. Hess, L.L.; Melack, J.M.; Novo, E.M.; Barbosa, C.C.; Gastil, M. Dual-season mapping of wetland inundation and vegetation for the central Amazon basin. Remote Sens. Environ. 2003, 87, 404-428. [CrossRef]

16. Schmidt, K.; Skidmore, A. Spectral discrimination of vegetation types in a coastal wetland. Remote Sens. Environ. 2003, 85, 92-108. [CrossRef]

17. Henderson, F.M.; Lewis, A.J. Radar detection of wetland ecosystems: A review. Int. J. Remote Sens. 2008, 29, 5809-5835. [CrossRef]

18. Petus, C.; Lewis, M.; White, D. Monitoring temporal dynamics of Great Artesian Basin wetland vegetation, Australia, using MODIS NDVI. Ecol. Indic. 2013, 34, 41-52. [CrossRef]

19. Wohlfart, C.; Liu, G.; Huang, C.; Kuenzer, C. A river basin over the course of time: Multi-temporal analyses of land surface dynamics in the Yellow River Basin (China) based on medium resolution remote sensing data. Remote Sens. 2016, 8, 186. [CrossRef]

20. Klein, I.; Gessner, U.; Dietz, A.J.; Kuenzer, C. Global WaterPack-A $250 \mathrm{~m}$ resolution dataset revealing the daily dynamics of global inland water bodies. Remote Sens. Environ. 2017, 198, 345-362. [CrossRef]

21. Martinis, S.; Kuenzer, C.; Wendleder, A.; Huth, J.; Twele, A.; Roth, A.; Dech, S. Comparing four operational SAR-based water and flood detection approaches. Int. J. Remote Sens. 2015, 36, 3519-3543. [CrossRef]

22. White, L.; Brisco, B.; Dabboor, M.; Schmitt, A.; Pratt, A. A collection of SAR methodologies for monitoring wetlands. Remote Sens. 2015, 7, 7615-7645. [CrossRef]

23. Smith, L.C. Satellite remote sensing of river inundation area, stage, and discharge: A review. Hydrol. Process. 1997, 11, 1427-1439. [CrossRef]

24. Hess, L.L.; Melack, J.M.; Simonett, D.S. Radar detection of flooding beneath the forest canopy: A review. Int. J. Remote Sens. 1990, 11, 1313-1325. [CrossRef]

25. Schmullius, C.; Evans, D. Review article Synthetic aperture radar (SAR) frequency and polarization requirements for applications in ecology, geology, hydrology, and oceanography: A tabular status quo after SIR-C/X-SAR. Int. J. Remote Sens. 1997, 18, 2713-2722. [CrossRef]

26. Kuenzer, C.; Bluemel, A.; Gebhardt, S.; Quoc, T.V.; Dech, S. Remote sensing of mangrove ecosystems: A review. Remote Sens. 2011, 3, 878-928. [CrossRef]

27. Kuenzer, C.; Knauer, K. Remote sensing of rice crop areas. Int. J. Remote Sens. 2013, 34, 2101-2139. [CrossRef]

28. Guo, M.; Li, J.; Sheng, C.; Xu, J.; Wu, L. A review of wetland remote sensing. Sensors 2017, 17, 777. [CrossRef] [PubMed]

29. Moreira, A.; Prats-Iraola, P.; Younis, M.; Krieger, G.; Hajnsek, I.; Papathanassiou, K.P. A tutorial on synthetic aperture radar. IEEE Geosci. Remote Sens. Mag. 2013, 1, 6-43. [CrossRef]

30. Ryu, J.H.; Choi, J.K.; Lee, Y.K. Potential of remote sensing in management of tidal flats: A case study of thematic mapping in the Korean tidal flats. Ocean Coast. Manag. 2014, 102, 458-470. [CrossRef]

31. Betbeder, J.; Rapinel, S.; Corpetti, T.; Pottier, E.; Corgne, S.; Hubert-Moy, L. Multitemporal classification of TerraSAR-X data for wetland vegetation mapping. J. Appl. Remote Sens. 2014, 8, 083648. [CrossRef]

32. Mitsch, W.; Gosselink, J. Wetlands, 4th ed.; Wiley: Hoboken, NJ, USA, 2007.

33. Keddy, P.A. Wetland Ecology: Principles and Conservation; Cambridge University Press: Cambridge, UK, 2010.

34. Tiner, R.W. Wetlands. An Overview. In Remote Sensing of Wetlands: Applications and Advances; CRC Press: Boca Raton, FL, USA, 2015; pp. 1-18.

35. Ramsar, Iran. Convention on wetlands of international importance, especially as waterfowl habitat. Ramsar (Iran) 1971, 1-3. 
36. Frazier, S.; International, W. An Overview of the World's Ramsar Sites; Wetlands International: Wageningen, The Netherlands, 1996.

37. Ramsar, Iran, 1971. Recommendation 4.7: Mechanisms for improved application of the Ramsar Convention. In Proceedings of the Meeting of the Conference of the Contracting Parties, Montreux, Switzerland, 27 June-4 July 1990; Volume 4.

38. Gade, M.; Melchionna, S.; Stelzer, K.; Kohlus, J. Multi-frequency SAR data help improving the monitoring of intertidal flats on the German North Sea coast. Estuar. Coast. Shelf Sci. 2014, 140, 32-42. [CrossRef]

39. Gade, M.; Wang, W.; Kemme, L. On the imaging of exposed intertidal flats by single-and dual-co-polarization Synthetic Aperture Radar. Remote Sens. Environ. 2018, 205, 315-328. [CrossRef]

40. Gade, M.; Melchionna, S. Joint use of multiple Synthetic Aperture Radar imagery for the detection of bivalve beds and morphological changes on intertidal flats. Estuar. Coast. Shelf Sci. 2016, 171, 1-10. [CrossRef]

41. Kim, D.J.; Moon, W.M.; Kim, G.; Park, S.E.; Lee, H. Submarine groundwater discharge in tidal flats revealed by space-borne synthetic aperture radar. Remote Sens. Environ. 2011, 115, 793-800. [CrossRef]

42. Jung, R.; Adolph, W.; Ehlers, M.; Farke, H. A multi-sensor approach for detecting the different land covers of tidal flats in the German Wadden Sea-A case study at Norderney. Remote Sens. Environ. 2015, 170, 188-202. [CrossRef]

43. Lee, Y.K.; Park, W.; Choi, J.K.; Ryu, J.H.; Won, J.S. Assessment of TerraSAR-X for mapping salt marsh. In Proceedings of the Geoscience and Remote Sensing Symposium (IGARSS), Vancouver, BC, Canada, 24-29 July 2011; pp. 2330-2333.

44. Da Lio, C.; Teatini, P.; Strozzi, T.; Tosi, L. Understanding land subsidence in salt marshes of the Venice Lagoon from SAR Interferometry and ground-based investigations. Remote Sens. Environ. 2018, 205, 56-70. [CrossRef]

45. Hong, S.H.; Wdowinski, S.; Kim, S.W. Evaluation of TerraSAR-X observations for wetland InSAR application. IEEE Trans. Geosci. Remote Sens. 2010, 48, 864-873. [CrossRef]

46. Hong, S.H.; Kim, H.O.; Wdowinski, S.; Feliciano, E. Evaluation of polarimetric SAR decomposition for classifying wetland vegetation types. Remote Sens. 2015, 7, 8563-8585. [CrossRef]

47. Lagomasino, D.; Fatoyinbo, T.; Lee, S.; Feliciano, E.; Trettin, C.; Simard, M. A comparison of mangrove canopy height using multiple independent measurements from land, air, and space. Remote Sens. 2016, 8, 327. [CrossRef] [PubMed]

48. Morishita, Y.; Hanssen, R.F. Temporal decorrelation in L-, C-, and X-band satellite radar interferometry for pasture on drained peat soils. IEEE Trans. Geosci. Remote Sens. 2015, 53, 1096-1104. [CrossRef]

49. Mahdianpari, M.; Salehi, B.; Mohammadimanesh, F.; Motagh, M. Random forest wetland classification using ALOS-2 L-band, RADARSAT-2 C-band, and TerraSAR-X imagery. ISPRS J. Photogramm. Remote Sens. 2017, 130, 13-31. [CrossRef]

50. Regmi, P.; Grosse, G.; Jones, M.C.; Jones, B.M.; Anthony, K.W. Characterizing post-drainage succession in thermokarst lake basins on the Seward Peninsula, Alaska with TerraSAR-X backscatter and Landsat-based NDVI data. Remote Sens. 2012, 4, 3741-3765. [CrossRef]

51. Wijaya, A.; Reddy Marpu, P.; Gloaguen, R. Discrimination of peatlands in tropical swamp forests using dual-polarimetric SAR and Landsat ETM data. Int. J. Image Data Fusion 2010, 1, 257-270. [CrossRef]

52. Englhart, S.; Keuck, V.; Siegert, F. Aboveground biomass retrieval in tropical forests-The potential of combined X-and L-band SAR data use. Remote Sens. Environ. 2011, 115, 1260-1271. [CrossRef]

53. Irwin, K.; Beaulne, D.; Braun, A.; Fotopoulos, G. Fusion of SAR, optical imagery and airborne LiDAR for surface water detection. Remote Sens. 2017, 9, 890. [CrossRef]

54. Parker, A.L.; Filmer, M.S.; Featherstone, W.E. First results from Sentinel-1A InSAR over Australia: Application to the Perth Basin. Remote Sens. 2017, 9, 299. [CrossRef]

55. Scott, D.; Jones, T. Classification and inventory of wetlands: A global overview. Vegetatio 1995, 118, 3-16. [CrossRef]

56. Ramsar Convention Secretariat. An introduction to the Convention on Wetlands (previously The Ramsar Convention Manual); CRC Press: Gland, Switzerland, 2016.

57. Lehner, B.; Döll, P. Development and validation of a global database of lakes, reservoirs and wetlands. J. Hydrol. 2004, 296, 1-22. [CrossRef] 
58. Knight, J.F.; Corcoran, J.M.; Rampi, L.P.; Pelletier, K.C. Theory and applications of object-based image analysis and emerging methods in wetland mapping. In Remote Sensing of Wetlands: Applications and Advances; CRC Press: Boca Raton, FL, USA, 2015; pp. 175-194.

59. Baghdadi, N.; Bernier, M.; Gauthier, R.; Neeson, I. Evaluation of C-band SAR data for wetlands mapping. Int. J. Remote Sens. 2001, 22, 71-88. [CrossRef]

60. Töyrä, J.; Pietroniro, A. Towards operational monitoring of a northern wetland using geomatics-based techniques. Remote Sens. Environ. 2005, 97, 174-191. [CrossRef]

61. Huang, S.; Potter, C.; Crabtree, R.L.; Hager, S.; Gross, P. Fusing optical and radar data to estimate sagebrush, herbaceous, and bare ground cover in Yellowstone. Remote Sens. Environ. 2010, 114, 251-264. [CrossRef]

62. Werninghaus, R.; Buckreuss, S. The TerraSAR-X mission and system design. IEEE Trans. Geosci. Remote Sens. 2010, 48, 606-614. [CrossRef]

63. Buckreuss, S.; Schattler, B. The TerraSAR-X ground segment. IEEE Trans. Geosci. Remote Sens. 2010, 48, 623-632. [CrossRef]

64. Dabrowska-Zielinska, K.; Budzynska, M.; Tomaszewska, M.; Malinska, A.; Gatkowska, M.; Bartold, M.; Malek, I. Assessment of carbon flux and soil moisture in wetlands applying Sentinel-1 Data. Remote Sens. 2016, 8, 756 .

65. Schmitt, A.; Wendleder, A.; Hinz, S. The Kennaugh element framework for multi-scale, multi-polarized, multi-temporal and multi-frequency SAR image preparation. ISPRS J. Photogramm. Remote Sens. 2015, 102, 122-139. [CrossRef]

66. Brisco, B. Mapping and monitoring surface water and wetlands with synthetic aperture radar. In Remote Sensing of Wetlands: Applications and Advances; CRC Press: Boca Raton, FL, USA, 2015; pp. 119-136.

67. Mitchell, A.; Milne, A.; Tapley, I. Towards an operational SAR monitoring system for monitoring environmental flows in the Macquarie Marshes. Wetl. Ecol. Manag. 2015, 23, 61-77. [CrossRef]

68. Moser, L.; Schmitt, A.; Wendleder, A.; Roth, A. Monitoring of the Lac Bam wetland extent using dual-polarized X-band SAR data. Remote Sens. 2016, 8, 302. [CrossRef]

69. Hajnsek, I.; Busche, T.; Krieger, G.; Zink, M.; Moreira, A. Announcement of Opportunity: TanDEM-X Science Phase; DLR Public Document TD-PD-PL-0032, Issue: 1.0, 19 May 2014; TanDEM-X Ground Segment, Microwaves and Radar Institute(DLR-HR), Wessling, Germany, pp. 1-27.

70. Heine, I.; Jagdhuber, T.; Itzerott, S. Classification and monitoring of reed belts using dual-polarimetric TerraSAR-X time series. Remote Sens. 2016, 8, 552. [CrossRef]

71. Mleczko, M.; Mróz, M. Wetland Mapping Using SAR Data from the Sentinel-1A and TanDEM-X Missions: A Comparative Study in the Biebrza Floodplain (Poland). Remote Sens. 2018, 10, 78. [CrossRef]

72. Otukei, J.R.; Blaschke, T.; Collins, M. Fusion of TerraSAR-x and Landsat ETM+ data for protected area mapping in Uganda. Int. J. Appl. Earth Obs. Geoinform. 2015, 38, 99-104. [CrossRef]

73. Ullmann, T.; Banks, S.N.; Schmitt, A.; Jagdhuber, T. Scattering characteristics of X-, C-and L-Band polsar data examined for the tundra environment of the Tuktoyaktuk Peninsula, Canada. Appl. Sci. 2017, 7, 595.

74. Wdowinski, S.; Amelung, F.; Kim, S.W.; Dixon, T. Wetland InSAR. In Remote Sensing of Wetlands: Applications and Advances; CRC Press: Boca Raton, FL, USA, 2015; p. 137.

75. Hammerson, G. Connecticut Wildlife: Biodiversity, Natural History, and Conservation; University Press of New England: Lebanon, NH, USA, 2004.

76. Schuster, C.; Schmidt, T.; Conrad, C.; Kleinschmit, B.; Förster, M. Grassland habitat mapping by intra-annual time series analysis-Comparison of RapidEye and TerraSAR-X satellite data. Int. J. Appl. Earth Obs. Geoinform. 2015, 34, 25-34. [CrossRef]

77. Jones, M.C.; Grosse, G.; Jones, B.M.; Walter Anthony, K. Peat accumulation in drained thermokarst lake basins in continuous, ice-rich permafrost, northern Seward Peninsula, Alaska. J. Geophys. Res. Biogeosci. 2012, 117. [CrossRef]

78. Cloude, S.R.; Pottier, E. An entropy based classification scheme for land applications of polarimetric SAR. IEEE Trans. Geosci. Remote Sens. 1997, 35, 68-78. [CrossRef]

79. Cloude, S.R.; Pottier, E. A review of target decomposition theorems in radar polarimetry. IEEE Trans. Geosci. Remote Sens. 1996, 34, 498-518. [CrossRef]

80. Betbeder, J.; Rapinel, S.; Corgne, S.; Pottier, E.; Hubert-Moy, L. TerraSAR-X dual-pol time-series for mapping of wetland vegetation. ISPRS J. Photogramm. Remote Sens. 2015, 107, 90-98. [CrossRef] 
81. Zalite, K.; Voormansik, K.; Olesk, A.; Noorma, M.; Reinart, A. Effects of inundated vegetation on X-band HH-VV backscatter and phase difference. IEEE J. Sel. Top. Appl. Earth Obs. Remote Sens. 2014, 7, 1402-1406. [CrossRef]

82. Tiner, R.W. Classification of wetland types for mapping and large-scale inventories. In Remote Sensing of Wetlands: Applications and Advances; CRC Press: Boca Raton, FL, USA, 2015; pp. 19-42.

83. Ullmann, T.; Schmitt, A.; Jagdhuber, T. Two component decomposition of dual polarimetric HH/VV SAR data: Case study for the tundra environment of the Mackenzie Delta region, Canada. Remote Sens. 2016, 8, 1027. [CrossRef]

84. Lee, Y.K.; Park, J.W.; Choi, J.K.; Oh, Y.; Won, J.S. Potential uses of TerraSAR-X for mapping herbaceous halophytes over salt marsh and tidal flats. Estuar. Coast. Shelf Sci. 2012, 115, 366-376. [CrossRef]

85. Ullmann, T.; Schmitt, A.; Roth, A.; Duffe, J.; Dech, S.; Hubberten, H.W.; Baumhauer, R. Land cover characterization and classification of arctic tundra environments by means of polarized synthetic aperture X-and C-Band Radar (PolSAR) and Landsat 8 multispectral imagery-Richards Island, Canada. Remote Sens. 2014, 6, 8565-8593. [CrossRef]

86. Rangoonwala, A.; Enwright, N.M.; Ramsey III, E.; Spruce, J.P. Radar and optical mapping of surge persistence and marsh dieback along the New Jersey Mid-Atlantic coast after Hurricane Sandy. Int. J. Remote Sens. 2016, 37, 1692-1713. [CrossRef]

87. Zhou, C.; Gong, H.; Chen, B.; Li, J.; Gao, M.; Zhu, F.; Chen, W.; Liang, Y. InSAR time-series analysis of land subsidence under different land use types in the Eastern Beijing Plain, China. Remote Sens. 2017, 9, 380. [CrossRef]

(C) 2018 by the authors. Licensee MDPI, Basel, Switzerland. This article is an open access article distributed under the terms and conditions of the Creative Commons Attribution (CC BY) license (http://creativecommons.org/licenses/by/4.0/). 